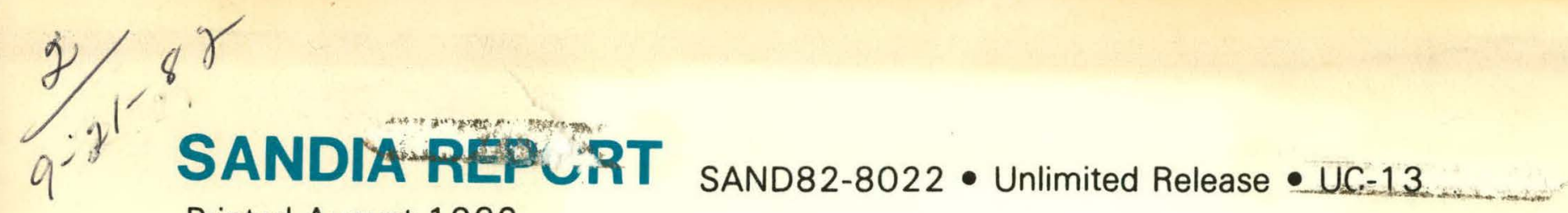

Printed August 1982

\title{
TARTNP User's Manual for Sandia National Laboratories
}

\section{DO NOT MICROFLLM MASTER}

G. J. Miller

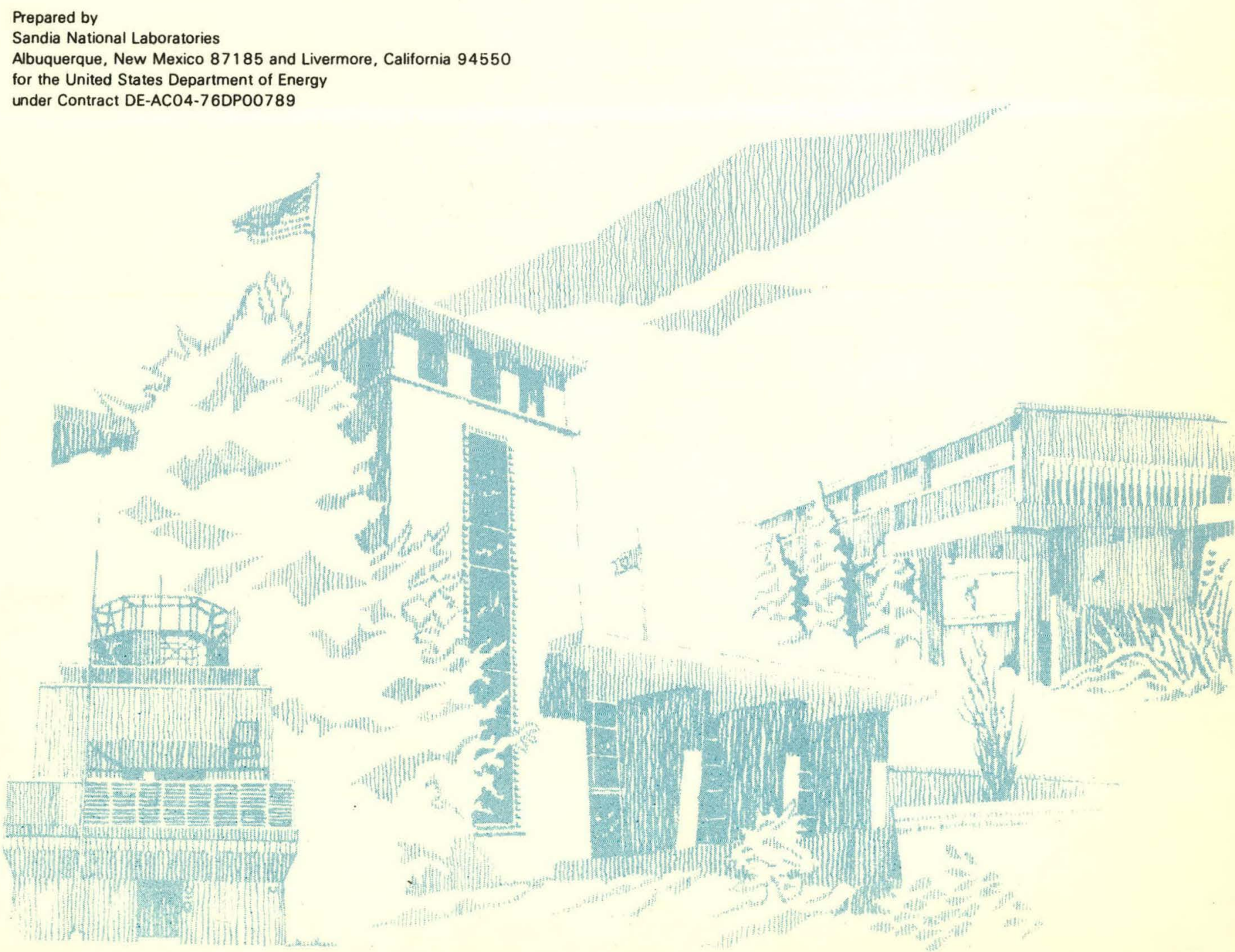




\section{DISCLAIMER}

This report was prepared as an account of work sponsored by an agency of the United States Government. Neither the United States Government nor any agency Thereof, nor any of their employees, makes any warranty, express or implied, or assumes any legal liability or responsibility for the accuracy, completeness, or usefulness of any information, apparatus, product, or process disclosed, or represents that its use would not infringe privately owned rights. Reference herein to any specific commercial product, process, or service by trade name, trademark, manufacturer, or otherwise does not necessarily constitute or imply its endorsement, recommendation, or favoring by the United States Government or any agency thereof. The views and opinions of authors expressed herein do not necessarily state or reflect those of the United States Government or any agency thereof. 


\section{DISCLAIMER}

Portions of this document may be illegible in electronic image products. Images are produced from the best available original document. 
Issued by Sandia National Laboratories, operated for the United States Department of Energy by Sandia Corporation.

NOTICE: This roport was preparen as an account of work sponsored by

an agency of the United States Government. Neither the United States

Government nor any agency thereof, nor any of their employees, nor any of the contractors, subcontractors, or their employees, makes any warranty, express or implied, or assumes any legal liability or responsibility for the accuracy, completeness, or usefulness of any information, apparatus, product, or process disclosed, or represents that its use would not infringe privately owned rights. Reference herein to any specific cummercial product, process, or servire hy trade name trademark, manufacturer, or otherwise, does not necessarily constitute or imply its endorsement, recommendation, or favoring by the United States Government, any agency thereof or any of their contractors of subcontractors. The views and opinions expressed herein do no necessarily state or reflect those of the United States Government, any agency thereof or any of their contractors or subcontractors. 


\section{PAGES 1 to 2 WERE INTENTIONALLY LEFT BLANK}


SAND82-8022

Unlimited Release

Printed August 1982
SAND $-82-8022$

DE82 021100

TARTNP USER'S MANUAL FOR SANDIA NATIONAL LABORATORIES

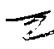

$\approx$

G. J. Miller

Scientific Computing Division

Sandia National Laboratories, Livermore

NOTICE

PORTIONS OF THIS REPORT ARE ILLEGIBLE. It Has Been Reproduced From The Best Available Copy To Permit The Broadest Possible Avait ability.

ABSTRACT

This report gives the operating instructions and input definitions for the TARTNP Monte Carlo neutron/photon transport code. It also describes the limitations of the code and the pitfalls that may be encountered in using it.

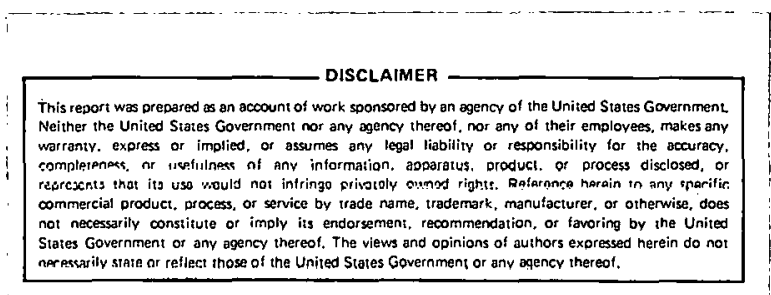




\section{ACKNOWLEDGMENTS}

The author is grateful to Gary Rodrigue for his assistance in making TARTNP available to SNLL.

The author is particularly indebted to Ernest Plechaty and John Kimlinger for their help in transferring the code to SNLL, for the unrestricted use of their code documentation, and for their considerable efforts in helping debug the SNLL version of the code. 


\section{FOREWORD}

This document and UCRL-50400 Vol. 14, "TARTNP: A Coupled Neutron-Photon Monte Carlo Transport Code," Ernest Plechaty and John Kimlinger, dated July. 4 , 1976, comprise the documentation for the TARTNP code at SNLL.

The UCRL-50400 document, which has been reprinted at SNLL, contains references to special Tally options that are not available in TARTNP at SNLL. They are Tally options $13,14,15$, and 17 .

This document is based on UCID-17026, "TARTNP User's Manual," J. Kimlinger and E. Plechaty, dated February 9, 1976: The basic format of that document has been retained as well as substantial portions that are relevant to the SNLL version of TARTNP. 


\section{CONTENTS}

Page

Introduction 11

TARTNP Operating Instructions

11

Restart Procedures

13

Restarting After an Interrupt

Units, Limitations, and Pitfalls

13

Units

Limitations

13

Pitfails

13

14

Code Input and Various Output Definitions $\quad 14$

APPENDIX A--LIST OF AVAILABLE ISOTOPES

APPENDIX B--NEUTRON ENERGY GROUPS $\quad 45$

APPENDIX C--PHOTON ENERGY GROUPS 47

APPENDIX D--TALLY GROUP LIMITS FOR NEUTRONS AND̃ PHOTONS · 49

APPENDIX E--LIMITS FOR TALLY TYPES 7,8,9, AND 10

APPENDIX F--PROGRAM TALLY 
TARTNP USER'S MANUAL FOR SANDIA NATIONAL LABORATORIES

\author{
Int roduction
}

The TARTNP operating instructions contain the information necessary to. start a problem and restart it after the termination of a run or after an error.

The limitations imposed on the code are dictated mainly by machine size. The code can check for certain geometric errors if the user exercises the options provided for that purpose.

The code-input section explains the significance of each input variable. The flexibility of the code is better understood after reading the entire input section.

\title{
TARTNP Operating Instructions
}

"The TARTNP code at" SNLL operates in batch mode on the CRAY." A procedure has been written which accesses the appropriate files and executes the program, thus freeing the user of the necessity of creating the Job Control Language (JCL) instructions. The procedure also provides options to manage a restart file(s) and files that result from using TARTNP Tally options 11,12 , or 16 . The code has restart capabilities upon normal termination; also after abnormal termination, provided the code has been in execution more than 12 minutes.

The procedure is invoked by a statement which in its most simple form is TARTNP , RSFN $=$ TARTSR1, RSFID $=$ GORDO, RSFPW $=\underline{X Y Z}$.

where the underlined arguments are user supplied, i.e., no defaults are furnished.

RSFN is Restart File Name

RSFID is Restart File ID

RSFPW is Restart File Maintenance Password

It is assumed, and the procedure requires, that these three arguments remain fixed for any series of runs. 
There are six arguments that can be added to the invoking statement which have both default and alternate values. They are

SRSF (NO:YES)
PRSF (NO:YES)
RS (NO:YES)
LMAP (OFF:FULL)
TALN (NO:YES)
TALP (NO:YES)

where the value preceding the colon is the default, the value following the colon the alternate. Any or all may be added to the TARTNP statement. Absence of the option variable yields the default, inclusion yields the alternate condition. The option variables are defined as follows

SRSF is Save Restart File

PRSt is Purge Restart File

RS is run will be a Restart.Run

LMAP is loader map sentinel

TALN is save Tally $(11,12$, or 16$)$ for Neutrons

TALP is save Tally. $(11,12$, or 16) for Photons

If PRSF is included, the file purging will occur before any other JCL instruction is executed, and will be of the highest available edition. If TALN and/or TALP are included, the saved permanent file(s) will be named TALLYN or TALLYP, respectively; and they will have the ID and PW defined on the TARTNP statement. No purging options have been included for these files since they will be automatically purged the next time the procedure is invoked.

A deck to execute TARTNF must include a front enld jub card, CRAY job and account cards, a card to access the procedure file, a library card, the procedure invoking card, a $7 / 8 / 9$ end-of-record card, and the TARTNP input cards as defined in this document. An illustration follows. The nonunderlined portions of the statements need to be as illustrated. In this example, an edition of the restart file is being purged and a new edition is being saved upon successful completion of the run.

GUM35,KUNC,STMFC. TEST OF TART GORDO BOX 15

JOB ,JN=GJM35, T=200, $K=$ UNC. TEST OF TART GORDO BOX 15

$A C C O U N T, A=0101010, E=22222, D=3333, R=P$.

$A C C E S S, D N=\overline{L F}, P D N=T A R T P R O C, I D=G O R D O$.

LIBRARY, DN $=L F, V$.

TARTNP, RSFN=TARTSR1, RSFID=GORDO, RSFPW $=\underline{X Y Z}, \mathrm{PRSF}, \mathrm{SRSF}$.

$7 / 8 / 9$

TARTNP input deck

$7 / 8 / 9$

Note that the procedure file is named TARTPROC. If for any reas on you might want a listing of the procedures, contact the author. It is not possible to obtain a listing of the procedure file. 
One last comment--the procedure is restricted to unclassified restart files. Additional access constraints will be needed for a classified file. The author will be glad to help create an appropriate JCL deck if/when the need arises.

\section{Restart Procedures}

When restarting TARTNP to cont inue a run that has terminated normally, it is necessary to add the RS argument to the procedure invocation statement, and also to change the value of $N 2$ on Card One of the TARTNP input deck.

\section{Restarting After an Interrupt}

- TARTNP will create a restart file after 12 minutes of execution and refresh the file every 12 minutes thereafter. If this file was saved.(SRSF included on the procedure invocation statement), one can restart TARTNP by adding an RS argument to the procedure invocation statement and by placing a 1 in Column Two of Card One of the input deck, i.e., define N2 to be 1 for this type of restart. The code will then complete execution to the number of samples originally requested.

\section{Units, Limitations, and Pitfalls}

\section{Units}

The code units are as follows.

\begin{tabular}{ll}
\hline Parameter & shake $\left(10^{-8} \mathrm{~s}\right)$ \\
\hline Time & $\begin{array}{l}\text { centimeter }(\mathrm{cm}) \\
\text { Length }\end{array}$ \\
$\begin{array}{l}\text { Centimeters per shake } \\
\text { millions of electron volts }(\mathrm{MeV})\end{array}$ \\
\hline
\end{tabular}

\section{Limitations}

The code limitations thät are currently imposed are as follows.

\begin{tabular}{ll}
\hline \multicolumn{1}{c}{ Quantity } & Limit \\
\hline Zones & 110 with five time edits \\
Quadratic boundary functions & 100 \\
Planes & 100 \\
Boundaries per zone & No limit \\
\hline
\end{tabular}




\begin{tabular}{lll}
\hline \multicolumn{1}{c}{ Quantity } & Neutrons & Photons \\
\hline Maximum input energy (MeV) & 20 & 20 \\
Minimum input energy (MeV) & $1.31 \times 10^{-9}$ & $10^{-3}$ \\
Materials & 20 & 20 \\
Isotopes in a material & No limit & No limit \\
Output tally groups & 50 & 50 \\
\hline
\end{tabular}

\section{Pitfalls}

All sources must, be generated inside the problem, but care must be taken in the interpretation of the problem if the sources are not generated in zones of equal statistical weight. If the output indicates a discrepancy in. neutron conservation, check the ratio of weights of adjacent zones or look for overlapping zones. In the geometry calculation a small quantity called FUDGE is added to the coordinates of the particle to move it of the boundary; this quantity should be no lärger than $\dot{U} .1$ of the thickness of the thinnest zone in the problem.

Code Input and Various Output Definitions

This section presents a card-by-card description of code input. The input cards described are listed below.

\begin{tabular}{|c|c|c|}
\hline $\begin{array}{l}\text { Input Card } \\
\text { No. }\end{array}$ & Type of Card & Sample of Information Contained \\
\hline 1 & $\begin{array}{l}\text { Control and } \\
\text { data }\end{array}$ & Restart, problem name \\
\hline 2 & Control & $\begin{array}{l}\text { Number of JPB cards, sample size, source type, } \\
\text { next problem }\end{array}$ \\
\hline 3 & Control & Spectrum type, reaction edit, number of materials \\
\hline $3 A$ & Control & Edit control, geometry debug \\
\hline 38 & Control & $\begin{array}{l}\text { Photon minimum energy, photon edit, } \\
\text { neutron/photon tracking control }\end{array}$ \\
\hline $3 C$ & Data & $\begin{array}{l}\text { Change neutron tracking energy group limits } \\
\text { (optional) }\end{array}$ \\
\hline 4 & Data & Change neutron tally group limits (optional) \\
\hline $4 A$ & Data & Change photon tally group limits (optional) \\
\hline
\end{tabular}




\begin{tabular}{|c|c|c|c|}
\hline $\begin{array}{l}\text { Input Card } \\
\text { No. }\end{array}$ & Type of & Card & Sample of Information Contained \\
\hline 5 & Data & & $\begin{array}{l}\text { Change energy group limits for neutron angular } \\
\text { tally (tally Types } 7,8,9,10) \text { (optional). }\end{array}$ \\
\hline $5 A$ & Data & & $\begin{array}{l}\text { Change energy group limits for photon angular } \\
\text { tally (tally Types } 7,8,9,10 \text { ) (optional). }\end{array}$ \\
\hline $5 B$ & Data & : & Reaction edits (neutrons only) (optional) \\
\hline 6 & Data & & JPBS \\
\hline 7 & Data & & FUDGE, source, angular distribution of source \\
\hline 8 & Data & & $\begin{array}{l}\text { Source energy, number of pairs in spectrum, } \\
\text { other source data }\end{array}$ \\
\hline 9 & Data & & Minimum energy, initial time, source data \\
\hline $9 A$ & Data & . & $\begin{array}{l}\text { Change cosine limits for neutron angular tallies } \\
\text { (optional) }\end{array}$ \\
\hline $9 B$ & Data & & $\begin{array}{l}\text { Change cosine limits for photon angular tallies } \\
\text { (optional) }\end{array}$ \\
\hline 10 & Data & & Conic surface boundary function \\
\hline 11 & Data & & Planes \\
\hline 12 & Data & $\cdots$ & $\begin{array}{l}\text { Material in a zone, statistical weight, tally } \\
\text { type units }\end{array}$ \\
\hline $12 \mathrm{~A}$ & Data & . & Geometrical debug parameters (optional) \\
\hline $12 B$ & Data & & Continuation of Card $12 \mathrm{~A}$ (optional) \\
\hline 14 & Data & & Time distribution of source (optional) \\
\hline 15 & Data & & Edit times \\
\hline $15 \mathrm{~A}$ & Data & & $\begin{array}{l}\text { Energy-dependént neutron output tally multipliers } \\
\text { (optional) }\end{array}$ \\
\hline $15 B$ & Data & . & $\begin{array}{l}\text { Energy-dependent photón output tally multipliers } \\
\text { (optional) }\end{array}$ \\
\hline 16 & Data & & Energy spectrum (optional) \\
\hline $17,17 \mathrm{~A}, 17 \mathrm{~B}$ & Data & ' & $\begin{array}{l}\text { Energy-angle-correlated source (optional) with } \\
\text { angular weighting function }\end{array}$ \\
\hline $17 \mathrm{C}, 170$ & Data & & Multiple-angle energy spectra (optional) \\
\hline
\end{tabular}




\begin{tabular}{|c|c|c|c|}
\hline No. & Type of & Card & Sample of Information Contained \\
\hline 18 & Data & & Isotopic composition of materials \\
\hline 19 & Data & & Isotopic composition of materials \\
\hline $19 \mathrm{~A}$ & Data & • & Problem multipliers (optional) \\
\hline $\begin{array}{l}20 \\
21\end{array}$ & Data & & Multishell (cylindrical or spherical) (optional) \\
\hline 22 & Data & & Surface source (optional) \\
\hline $\begin{array}{l}23 \\
24\end{array}$ & Data & & $\begin{array}{l}\text { Source information for Tally Types } 18 \text { and } 19 \\
\text { (optional) }\end{array}$ \\
\hline
\end{tabular}

Following the title of certain cards and preceding the format appears the word "optional" in parentheses; this indicates that use of the card is optional and that it must be requested by some prior input sentinel. All other cards are necessary.

In punching cards, one should observe the following instructions:

1. Plus signs need not be punched.

2. A blank field is the same as a zero.

.3. rloating-point numbers require a decimal point and may st.art. at. any column within their fields (usually 12 columns).

4. Input integers (fixed) must be right-adjusted with in their fields (usually four columns).

INPUT CARD 1. RESTART, PROBLEM NAME

Format (I2, I1, 4A8, A5)

\begin{tabular}{|c|c|c|}
\hline Columns & Name & Description \\
\hline $1-2$ & N2 & $\begin{array}{l}\text { Blank initially; if the code has created a restartable } \\
\text { dump tape, this card must be used with the normal contrul } \\
\text { cards, with a } 1 \text { 1nscrted in Culumin } 2 \text {. If on restart a } 2 \\
\text { is put in Column } 2 \text {, the code gives a full set of output } \\
\text { tallies and continues to run to normal completion. If on } \\
\text { restart a number greater than } 2 \text { is entered, the number of } \\
\text { samples will. be replaced by that number. }\end{array}$ \\
\hline 3 & NCHAIN & NCHAIN = 0 , neutronics and photonics transport. \\
\hline $4-40$ & HEAD & Problem name (alphanumeric). \\
\hline
\end{tabular}


INPUT CARD 2. NUMBER OF JPB CARDS, SAMPLE SIZE, SOURCE TYPE, NEXT PROBLEM

Format (7I4, I8, 9I4)

\begin{tabular}{|c|c|c|}
\hline Columns & Name & Description \\
\hline $1-4$ & NGZ & $\begin{array}{l}\text { Number of material-in-a-zone cards to be read in (see } \\
\text { Card } 12 \text { ). }\end{array}$ \\
\hline $5-8$ & NG & Number of JPB cards to be read (see Card 6 ). \\
\hline $9-12$ & IPX & $\begin{array}{l}\text { Number of conic surfaces (see Card 10). The functional } \\
\text { form of these surfaces is }\end{array}$ \\
\hline & & $A\left(x-x_{0}\right)^{2}+B\left(y-y_{0}\right)^{2}+C\left(z-z_{0}\right)^{2}=k^{2}$ \\
\hline $13-16$ & IPL & $\begin{array}{l}\text { Number of plane surfaces (see Card 11). The functional } \\
\text { form of these surfaces is } x=M_{1}, y=M_{2} \text {, or } z=M_{3} \text {. }\end{array}$ \\
\hline $17-20$ & IX8 & Number of planes perpendicular to the $x$-axis. \\
\hline $21-24$ & IY9. & Number of planes perpendicular to the $y$-axis. \\
\hline $25-28$ & NSORS & $\begin{array}{l}\text { Number of samples. This is the number of times the } \\
\text { problem is to be replicated for the purpose of estimating } \\
\text { standard deviations. The number should be } 20 \text { or more. }\end{array}$ \\
\hline $29-36$ & NSAMP & $\begin{array}{l}\text { Sample size. The total number of particle histories in } \\
\text { the problem is the sample size multiplied by the number } \\
\text { of samples. }\end{array}$ \\
\hline $37-40$ & S1 & Source indicator (ICOOD). \\
\hline & & $S 1=1:$ A point source at $x=S 3, y=\$ 4, z=\$ 5$. \\
\hline . & . & $\begin{array}{l}S 1=2: \text { A source uniformly distributed in a cylindrical } \\
\text { volume with } R_{i n n e r}=S 3, R_{\text {outer }}=S 4 \text {, and length } z \text {, } \\
\text { where } S 5 \cdot z<(S 5+S 9) \text {. The cylinder is centered at } \\
x_{0}=S 10 \text { and } y_{0}=S 11 .\end{array}$ \\
\hline & & Note: If $S 9=0.0$, the source is a disk at $z=S 5$. \\
\hline & & $\begin{array}{l}S 1=3: \text { A source uniformly distributed in a spherical } \\
\text { shell or a. segment of a spherical shell with } R_{i}=S 3 \text {, } \\
R_{0}=S 4 \text {, centered at } x_{0}=S 10, y_{0}=S 11 \text {, and } z_{0}=S 5 . \\
\text { The segment generated is given by } \cos \theta=S 8 * R+S 15 \text {, } \\
\text { Where } \cos \theta \text { is relative to the } z-a x i s \text { and } R \text { is a random } \\
\text { number. (To generate throughout a complete sphere, } \\
S 8=2.0 \text { and } S 15=-1.0 .)\end{array}$ \\
\hline & & $\begin{array}{l}S 1=4: \text { A source uniformly distributed on a segment of a } \\
\text { spherical surface. The shell is centered at } x_{0}=S 10 \text {, } \\
\text { yo }=S 11 \text {, and } z_{0}=S 5 \text {, with radius } S 9 . \text { The segment } \\
\text { generated is determined as in } S 1=3 \text {. }\end{array}$ \\
\hline
\end{tabular}


INPUT CARD 2 (cont.)

Columns Name $\quad$ Description

$37-40 \quad S 1$ (cont.)
$S 1=5$ : Source is a line, plane, or rectangular volume distributed over the surface defined by

$$
\begin{aligned}
& S 3<x<(S 3+S 10) \\
& S 4<y<(S 4+S 11) \\
& S 5<z<(S 5+S 12)
\end{aligned}
$$

S1 $=6$ : A point source at $x=S 3, y=S 4$, and $z=S 5$, with the reference direction for its angular distribution defined by the line joining the source point and the point $(S 10, S 11, S 12)$. This source should not be used if $\$ 3=\$ 4=\$ 10-\$ 11-0.0$.

S1 = 7: A source uniformly distributed over the surface af an inclined d1sk of inner radius $\$ 3$ and outer radius S4. The disk is tangent at its center $(x=S 10, z=S 11)$ to a sphere of radius S5 centered at $(0.0,0.0, S 12)$. The reference direction for the angular distribution is from $(S 10,0.0, S 11)$ to $(0.0,0.0, S 12)$. If the disk is not rotated, use $S 1=2$.

$\mathrm{Sl}=8$ : A source uniformly distributed over the surface of an inclined isosceles triangle of height $\$ 3$ and half-base 54 . The triangle is tangent at its vertex to a sphere of radius $S 5$ that is centered at $(0.0,0.0, S 12)$. The reference direction for the angular distribution is from $(S 10,0.0, S 11)$ to $(0.0,0.0, S 12)$.

$s 1=9:$ A source uniformly distributed throughout the volume of up to 15 spherical shells (ur styminils of spherical shells). The choice of shell is determined by input probabilities (relative number in each shell). The segment generated is determined as in $\mathrm{S} 1=3$. Additional input required is to be on Cards 20 and 21 .

$S 1=10:$ The same as $S 1=9$, except that the shells are cylindrical. Part of the input is $\Delta_{z}$, which is the length of the cylinder. Additional input is to be punched on lards 20 and 21 .

$S 1=11:$ A source uniformly distributed on one or more surfaces (maximum of 10) and directed inward with a cosine distribution. The surfaces may be cones, spheres, cylinders, or circular disks, as described by Card 22. The number of surfaces and the relative number of particles on each surface are described by Card 20 .

$\underline{S 1=12}$ : Not used. 


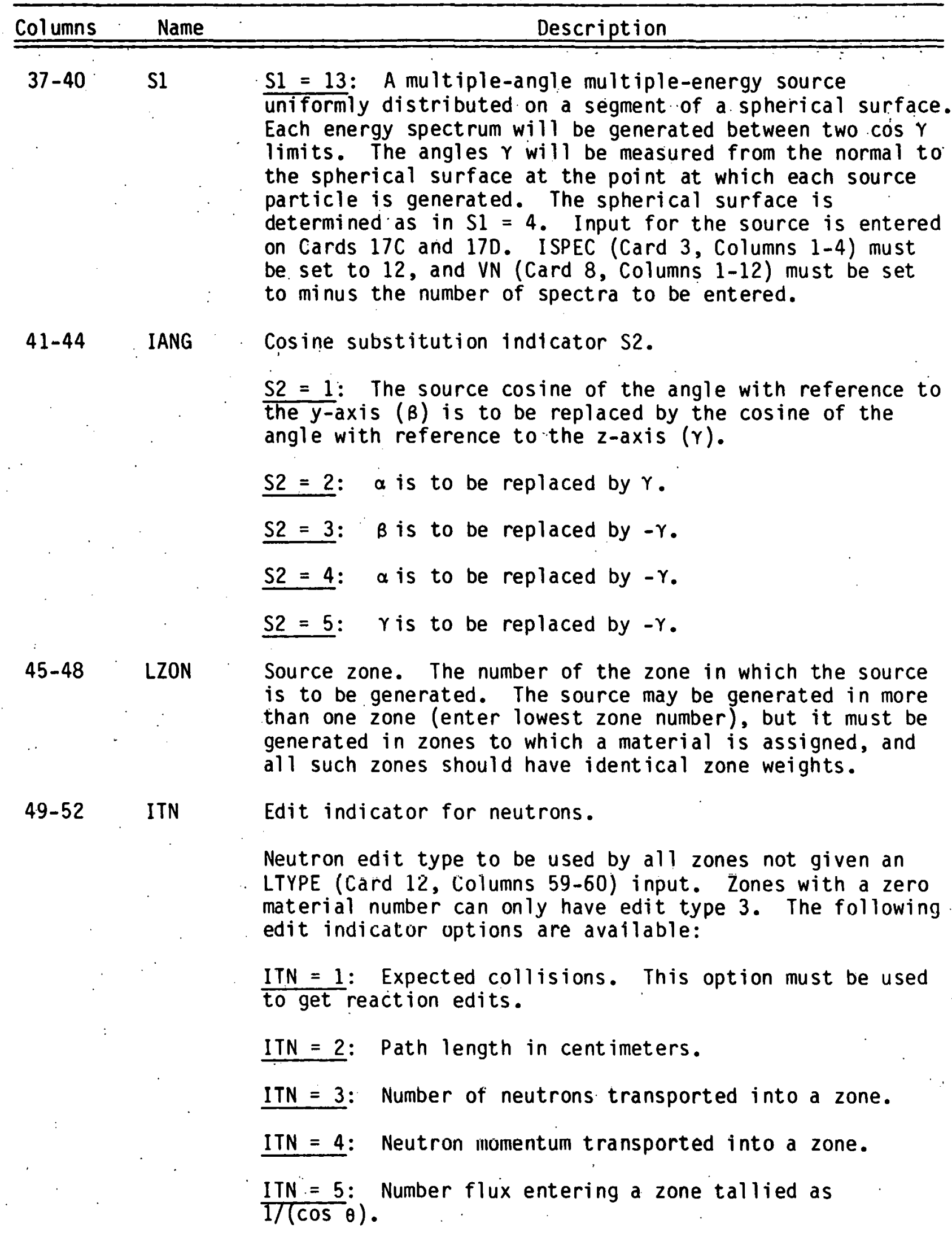




Columns Name Description $\quad$ D

49-52 ITN ITN =6: Momentum flux entering a zone.

(cont.).

ITN $=7^{*}:$ Same as $I T N=3$, but a time-independent

angular distribution is added.

ITN $=8 *:$ Number of neutrons transported into a zone as

a function of energy tallied as $1 /(\cos \theta)$, where $\cos \theta$ is the angle relative to the normal.

ITN = 9*: Momentum entering a zone as a function of energ.y and a time-independent angular distribution.

ITN $=10^{*}$ : Momentum flux entering a zone as a function

of energy and a time-independent angular distribution tallied as $V /(\cos \theta)$.

ITN = 11: - See the note in this section. Will create a disc fite of the coordinates of particles entering a zone in the form of

$$
\begin{aligned}
& \text { Word } 1=x^{2}+y^{2} \\
& \text { Word } 2=z \\
& \text { Word } 3=V \\
& \text { Word } 4=T \\
& \text { Word } 5=L \\
& \text { Word } 6=\text { NS } \\
& \text { Word } 7=\text { N.SR }
\end{aligned}
$$

where $x, y$, and $z$ are particle coordinates, $V$ is velocity, $T$ is time, $L$ is zone number, NS is particle number, and NSR is sample number.

NOTE: Tally Types 11, 12, or 16 can and will create huge files unless their use is limited to one or two zones, the problem run is of limited duration, and provided judicinus care is lised in identifying the zone(s) of interest. This latter can be accomplished in two ways.

The first is to set ITN to 11,12 , or 16 , in which case the material. in a zone card (input Card 12) for all other zones must be modified by changing LTYPE (Column 60) to 3. Failure to do this will result in the ITN tally being generated for all zones which would generate a file you would neither want to create nor subsequently read.

A second and better way to activate any of these tally options is to leave ITN blank and to change LTYPE (input Card 12) on the one or two zones of interest to be 11 , 12 , or 16. In this instance all other zones will be set to the default value of $1 \mathrm{ITN}=3$.

* Limits for this type of tally are 50 zones, 19 angles, 24 energy bins. 


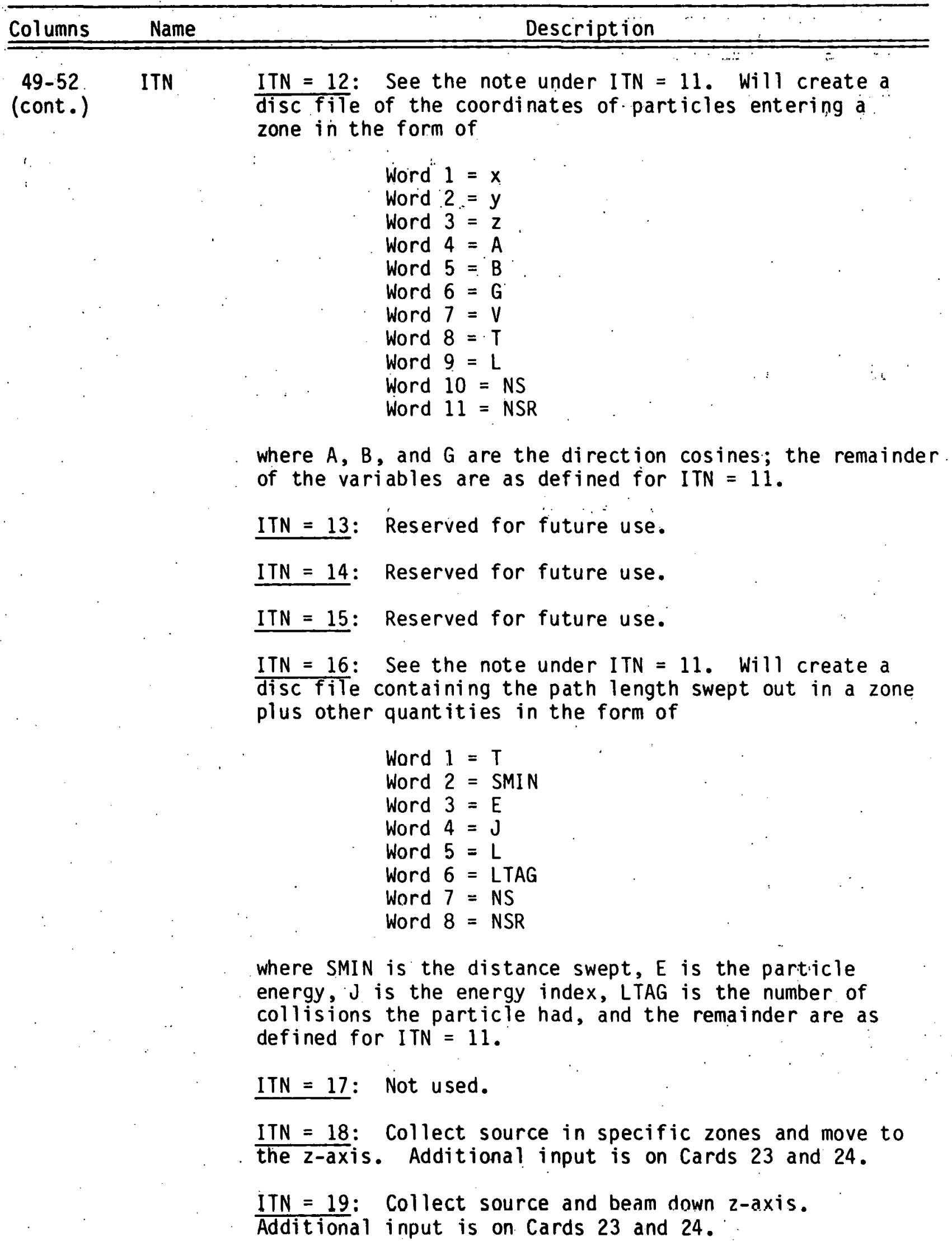




\begin{tabular}{|c|c|c|}
\hline Columns & Name & Description \\
\hline $\begin{array}{l}49-52 \\
(\text { cont. })\end{array}$ & ITN & ITN $=20:$ Monte Carlo collisions. \\
\hline (2) & . & $\begin{array}{l}\text { The above ITN tallies are time- and energy-dependent and } \\
\text { are normalized to one source neutron. In addition the } \\
\text { energy deposition, expressed in MeV/zone, is also given.* } \\
\text { (This is independent of the chosen edit type.) Using } \\
\text { problem or zone mult ipliers, the energy deposition and } \\
\text { fissions, expressed in MeV per gram of zone if the edit } \\
\text { indicator is plus or in MeV per cubic centimeter of zone } \\
\text { if the edit indicator is minus, are modified by the } \\
\text { multiplier. }\end{array}$ \\
\hline $53-56$ & ITM & $\begin{array}{l}\text { Type of time distribution. With an entry of } 0 \text { or } 1 \text {, all } \\
\text { source particles are generated with the same time } \\
\text { coordinate. With an entry of } 2 \text { or greater, source } \\
\text { particles are generated with a time coordinate picked } \\
\text { from a given distribution of that many time entries on } \\
\text { Card } 14 \text {. A negative entry signals that a time spectrum } \\
\text { of that many pairs of points } N(T) \text { and } T \text { will be input on } \\
\text { Card } 14 \text {. }\end{array}$ \\
\hline $57-60$ & IM & $\begin{array}{l}\text { Number of edit times. The number of time intervals into } \\
\text { which the problem has been divided for recording output. } \\
\text { Maximum number is } 5 \text { (see edit times, Card 15). }\end{array}$ \\
\hline $61-64$ & ITX & $\begin{array}{l}\text { The number of cosine limits for tallying neutron angular } \\
\text { distributions. Maximum allowed is } 20 \text {. If ITX is zero, } \\
\text { the code uses the fulluwing set of cosines: } 1.0,0.98 \text {, } \\
0.95,0.90,0.82,0.72,0.60,0.40,0.20,0.05,-0.05 \text {, } \\
-0.20,-0.40,-0.60,-0.12,-0.82,-0.90,-0.45,-0.98 \text {, } \\
-1.0 \text { (see Card 9A). }\end{array}$ \\
\hline $65-68$ & MORE & Not. "ISed. \\
\hline $69-72$ & NX & $\begin{array}{l}\text { Next problem sentinel. Enter } 1 \text { if another problem deck } \\
\text { immediately follows the current one. }\end{array}$ \\
\hline $\begin{array}{l}\text { * See pro } \\
\text { units. }\end{array}$ & & multipliers (Cards. 12 and 19A) for the conversion of \\
\hline
\end{tabular}


INPUT CARD 3. SPECTRUM TYPE, DATA TAPE, REACTION EDIT, NUMBER OF MATERIALS Format $(314,12 X, 1114)$

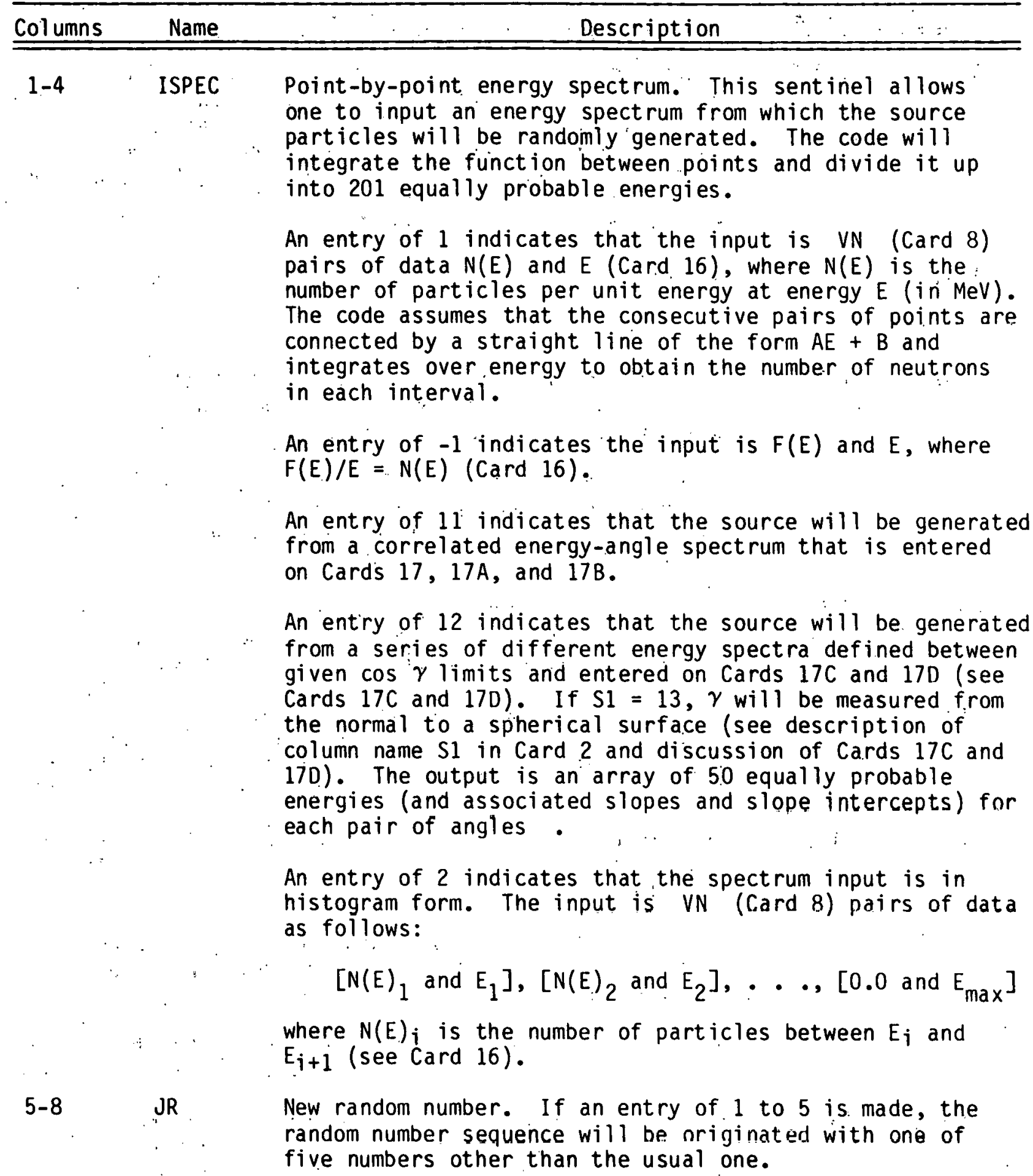


INPUT CARD 3 (cont.)

\begin{tabular}{|c|c|c|}
\hline Col umns & Name & Description \\
\hline $9-12$ & IEDIF & $\begin{array}{l}\text { Neutron-energy-difference edit indicator. With an entry } \\
\text { of } 1 \text {, the neutron output distributions that are a function } \\
\text { of zone, energy, and time will be repeated, but with each } \\
\text { tally divided by the difference in energy between each } \\
\text { neutron tally group. With an entry of } 2 \text {, the output will } \\
\text { be multiplied by an input constant for each tally group } \\
\text { that is read in on Card } 15 \mathrm{~A} \text {. }\end{array}$ \\
\hline $13-16$ & JQ & Not used. \\
\hline $21-24$ & IAI & Not used. \\
\hline $25-28$ & IA3 & $\begin{array}{l}\text { Angular distribution intervals. If left blank, the code } \\
\text { will assign } 16 \text { intervals to each anisotropic angular } \\
\text { distrifinfinn. Ont.1nnal input is } 8 \text { or } 4 \text {. }\end{array}$ \\
\hline $29-32$ & IA5 & $\begin{array}{l}\text { Change number of groups. This sentinel is the number of } \\
\text { group limits to be read in on Card } 3 \mathrm{C} \text { if the standard } \\
\text { number of groups is not used. If this entry is left } \\
\text { blank, } 175 \text { groups are followed. }\end{array}$ \\
\hline $33-36$ & IA6 & $\begin{array}{l}\text { Store cross-section sentinel.. If } 1 \text {, the total cross } \\
\text { sections are not stored away by the generator. Normal } \\
\text { usage requires this sentinel to be left blank. }\end{array}$ \\
\hline $37-40$ & IA] & $\begin{array}{l}\text { Collision sentinel. If this sentinel is blank, neutron- } \\
\text { emission probabilities will be used in the collision } \\
\text { routine. An entry of } 1 \text { allows react ion probabilities to } \\
\text { be used. If } 1 \text { is used, IAlO should also be } 1 \text {. }\end{array}$ \\
\hline $41-44$ & I13 & $\begin{array}{l}\text { Read in problem multipliers. This entry is the number of } \\
\text { problem multipliers to be entered on Card 19A. The } \\
\text { maximum is } 5 \text {. }\end{array}$ \\
\hline $45-48$ & IA9 & $\begin{array}{l}\text { Reaction-edit sentinel. [nter the number of zones for } \\
\text { which edits by reaction are requested. The input for } \\
\text { these edits is on Card } 5 \bar{B} \text {. }\end{array}$ \\
\hline $49-52$ & IAIO & $\begin{array}{l}\text { Reaction list. } 1 A 10=0 \text { for emission neutronics, } 1 A 10=1 \\
\text { for reaction neutronics and } M C M E G, 1 A 10=2 \text { for } N I X O N .\end{array}$ \\
\hline $53-56$ & IAlI & $\begin{array}{l}\text { Change neutron or photon tally groups. An entry of } 1 \\
\text { will allow the neutron-output tally groups to be changed. } \\
\text { Input is on Card } 4 \text {. An entry of } 2 \text { will change the phot on } \\
\text { tally groups. Input is on Card } 4 A \text {. An entry of } 3 \text { will } \\
\text { change both neutron and photon tally groups (Cards } 4 \text { and } \\
4 A) \text { : }\end{array}$ \\
\hline $61-64$ & IA13 & $\begin{array}{l}\text { Photon fluorescence. If } 1 \text { is entered, fluorescent } \\
\text { photons will be transported. }\end{array}$ \\
\hline
\end{tabular}




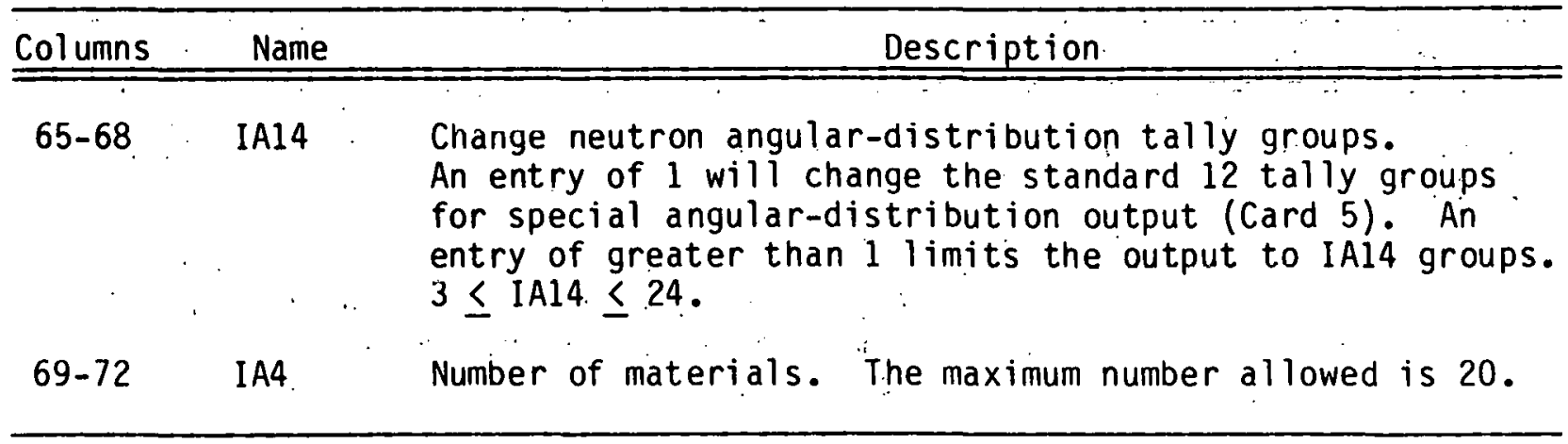

INPUT CARD 3A. EDIT CONTROL, GEOMETRY DEBUG, TAPE (TALLY TYPES 11 AND 12) Format $(8 X, I 4,16 X, 4 I 4,8 X, I 4)$

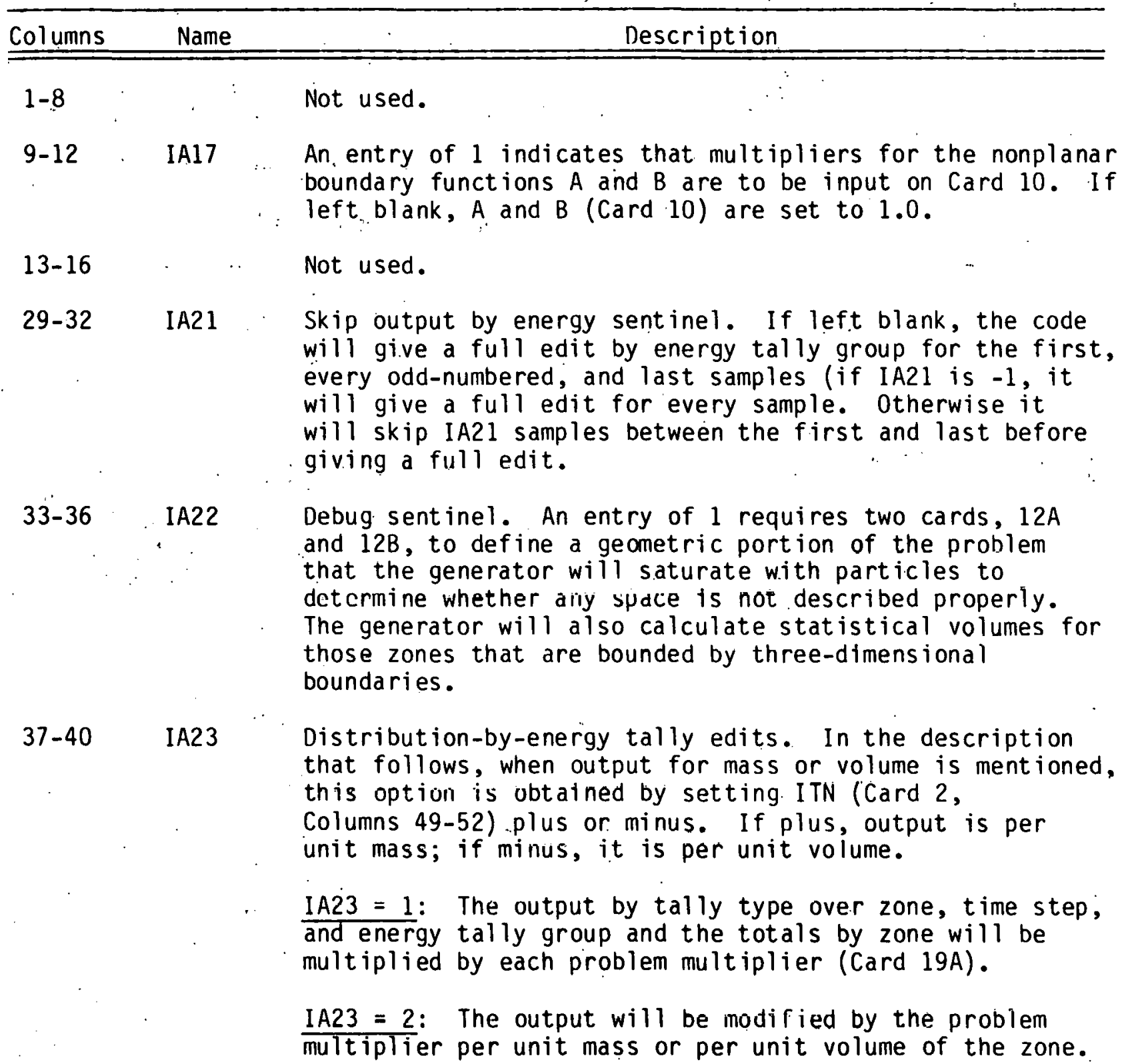


INPUT CARD 3A (cont.)

\begin{tabular}{|c|c|c|}
\hline Columns & Name & Description \\
\hline $\begin{array}{l}37-40 \\
(\text { cont. })\end{array}$ & IA23 & $\begin{array}{l}\text { IA23 = 3: The output will be modified by the problem: } \\
\text { multiplier times the zone multiplier (Card } 12 \text {, } \\
\text { Columns } 61-72 \text { ). }\end{array}$ \\
\hline & & $\begin{array}{l}\text { IA23 }=4 \text { : The output will be modified by the problem } \\
\text { multiplier times the zone multiplier per unit mass or per } \\
\text { unit volume of the zone. } \\
\text { IA23 }=5 \text { : The output will be modified by the problem } \\
\text { multiplier times the zone multiplier times the energy } \\
\text { multiplier defined by IEDIF (Card } 3 \text {, Columns } 9-12 \text { ). }\end{array}$ \\
\hline $41-44$ & IA24 & Flux tally edits. \\
\hline & & $\begin{array}{l}\text { IA24 = 1; The angular-distribution output (from tally } \\
\text { Types } \% \text {, } y \text {, or } 10 \text { ) by culle, angular group, and angular. } \\
\text { energy group will be multiplied by each problem multiplier } \\
\text { IA24 }=2,3,4 \text { : The output will be modified as IA23. }\end{array}$ \\
\hline $53-56$ & IA27 & IA27 = $1:$ List the changed cross sections. \\
\hline
\end{tabular}

INPUT CARD 3B. PHOTON MINIMUM ENERGY, PHOTON EDIT, NEUTRON/PHOTON TRACKING CONTROL

Format $(F 12.5,514)$

\begin{tabular}{|c|c|c|}
\hline Columns & Name & Description \\
\hline $1-12$ & EMIN & $\begin{array}{l}\text { Minimum energy for photons. If a positive value is } \\
\text { entered, this is the minimum value a scattered photon may } \\
\text { have. If a negat ive value is entered and a photon } \\
\text { scatters below this value, it is discarded and tallied } \\
\text { under "energy yain" in the photon edil. If left blank, } \\
\text { the code enters -0.001 as EMIN. }\end{array}$ \\
\hline $13-16$ & ITNG & $\begin{array}{l}\text { See the note under ITN }=11 \text {. It is applicable, } \\
\text { substituting ITNG for ITN and LTYPEG for LTYPE. } \\
\text { Edit indicator for photons. Photon edit type to be used } \\
\text { by all zones not given an LTYPEG (Card } 12 \text {, Columns 55-57) } \\
\text { tally type. If left blank, ITNG is set to } 3 \text { (photons } \\
\text { transported into a zone). See ITN, Card 2, Columns 49-52, } \\
\text { for a description of available indicators. }\end{array}$ \\
\hline
\end{tabular}




\begin{tabular}{|c|c|c|}
\hline Columns & Name & Description \\
\hline $17-20$ & IAI 4G & $\begin{array}{l}\text { Change photon angular-distribution tally groups. An } \\
\text { entry of. } 1 \text { will change the standard } 12 \text { tally groups for } \\
\text { special angular-distribution output (ITNG }=7,8 \text {, } 9 \text {, or } \\
\text { 10). Input for these changes is. on Card } 5 A \text {. An entry of } \\
\text { greater than } 1 \text { limits the output to IAl4G groups } \\
(3 \leq \text { IAI4G } \leq 24) \text {. }\end{array}$ \\
\hline $21-24$ & ITXG & $\begin{array}{l}\text { The number of cosine limits for tallying photon angular } \\
\text { distributions. Maximum is } 20 \text {. See ITX, Card } 2 \text {, } \\
\text { Columns } 61-64 \text {, for standard limits. New limits are read } \\
\text { in on Card 9B. }\end{array}$ \\
\hline $25-28$ & INEUT & $\begin{array}{l}\text { Particle-following sentinel. If } 0 \text {, neutrons and neutron- } \\
\text { induced photons will be followed. If INEUT }=1 \text {, only } \\
\text { neutrons will be followed. If INEUT }=2 \text {, only photons } \\
\text { will be followed. }\end{array}$ \\
\hline $29-32$ & IGSENT & $\begin{array}{l}\text { Edit indicator for photon energy difference. With an } \\
\text { entry of } 1 \text {, the photon output distributions that are a } \\
\text { function of zone, time, and energy will be repeated, but } \\
\text { with each tally divided by the difference in energy } \\
\text { between each photon tally group. With an entry of } 2 \text {, the } \\
\text { output will be multiplied by an input constant for each } \\
\text { tally group that is read in on Card } 15 \mathrm{~B} \text {. }\end{array}$ \\
\hline
\end{tabular}

INPUT CARD 3C. CHANGE NEUTRON-TRACKING ENERGY GROUP LIMITS (optional) Format (18I4)

Columns , Name $\quad$ Description

$1-72, \quad$ IL

Neutron-following group 1 illits. If IA5 is nonzero, IA5 new group limits will be entered, 18 to a card. These 11 mits are based on the standard 176 limits. A minimum of 5 and a maximum of 174 can be entered. The set of new limits must include the following: $1,7,25,92,114$, and 176. 
INPUT CARD 4. CHANGE NEUTRON TALLY GROUP LIMITS (optional) Format (18I4)

\begin{tabular}{|c|c|c|}
\hline Columns & Name & Description \\
\hline $1-72$ & ITAP & $\begin{array}{l}\text { New neutron tally group limits. If IAll (Card } 3 \text {, } \\
\text { Columns } 53-56 \text { ) is } 1 \text { or } 3 \text {, three cards with the format } \\
\text { (18I4) are needed to supply the new } 51 \text { group limits. } \\
\text { These numbers are based on the initial group limits that } \\
\text { the code uses for cross-sect ion input. of the } 51 \text { limits, } \\
\text { the first and last ones must be } 1 \text { and } 176 \text {. }\end{array}$ \\
\hline
\end{tabular}

INPUT CARD 4A. CHANGE PHOTON TALLY GROUP LIMITS (optionaI) Format (1814)

\begin{tabular}{|c|c|c|}
\hline Columns & Name & Description \\
\hline \multirow[t]{2}{*}{$1-72$} & ITAPG & $\begin{array}{l}\text { New photon tally group limits. If IAll (Card } 3 \text {, } \\
\text { Columns } 53-56 \text { ) is } 2 \text { or } 3 \text {, three cards are needed to } \\
\text { supply the new photon tally group limits, which range } \\
\text { from } 1 \text { to } 144 \text {. }\end{array}$ \\
\hline & INPUT CARD 5. & $\begin{array}{l}\text { CHANGE ENERGY GROUP LIMITS FOR NEUTRON ANGULAR TALLY } \\
\text { (Tally Types } 7,8,9,10) \text { (optional) }\end{array}$ \\
\hline Columns & Name & Description \\
\hline $1-72$ & ILAP & $\begin{array}{l}\text { New neutron angular-distribution tally energy group } \\
\text { limits. If IAl4 is zero, this card is not used. If IAl4 } \\
\text { is } 1 \text {, new limits are to be entered based. on the } 51 \text { group } \\
\text { neutron tally limits. of the } 13 \text { limits, the first and } \\
\text { the last must be } 1 \text { and } 51 \text {, If IAl4 is other than } 1 \text {, } \\
\text { IA14 }+1 \text { limits are entered, IA } 14 \text { cannot be greater } \\
\text { than } 24 \text {. }\end{array}$ \\
\hline
\end{tabular}

INPUT CARD 5A. CHANGE ENERGY GROUP LIMITS FOR PHOTON ANGULAR TALLY (Tally Types $7,8,9,10)$ (optional) Format (1814)

\begin{tabular}{|c|c|c|}
\hline Columns & Name & Description \\
\hline $1-72$ & IAl4G & $\begin{array}{l}\text { New photon angular-distribution tally group limits. If } \\
\text { IAl4G is } 1 \text {, } 13 \text { new limits are to be entered based on the } \\
51 \text { group photon tally limits. The first should be } 1 \text {, and } \\
\text { the last should be } 51 \text {. If IA14G is greater than } 1 \text {, } \\
\text { IA14G + } 1 \text { limits are entered. (IA14G } \leq 24 . \text { ) }\end{array}$ \\
\hline
\end{tabular}


INPUT CARD 5B. REACTION EDITS (optional) Format $(14,1116)$

\begin{tabular}{|c|c|c|}
\hline Columns & Name & Description \\
\hline $1-70$ & & Reaction-edit input. \\
\hline $1-4$ & $L$ & Zone to be edited. \\
\hline $5-70$ & LI & $\begin{array}{l}\text { Isotopes to be edited: Format (11I6). If left blank, } \\
\text { all the reactions of all the isotopes in the zone will be } \\
\text { individually tallied; otherwise only the isotopes } \\
\text { requested will be edited by reaction. A zone must be } \\
\text { assigned Tally Type } 1 \text { (expected collisions) or Type } 20 \\
\text { (Monte Carlo collisions) to be edited. IA9 (Card 3, } \\
\text { Column 48) of these cards will be read in. }\end{array}$ \\
\hline
\end{tabular}

INPUT CARD 6. JPB ZONE DESCRIPTION Format (18I4)

Columns Name Description $\quad$ D

1-72 JZOND JPB zone description. There is a maximum of nine sets of JPB values for each card. More than one card may be used to describe one zone. An entry of 1 in Column 73 signals that the next card of values is a continuation of the description of that zone. Each set is associated with one boundary of the zone. If a zone has fewer than nine boundaries, the remaining sets are left blank. $B$ is the boundary number, negative for a plane and positive for a conic (any nonplanar boundary). $P$ is the zone that a particle will most probably enter when it crosses boundary $B$. If more than one zone applies, $P$ should be the zone having the lowest number. $J$ is the sign of $P$.

Rules for Conic Boundary Functions Described by:

$$
A\left(x-x_{0}\right)^{2}+B\left(y-y_{0}\right)^{2}+C\left(z-z_{0}\right)^{2}=k^{2}
$$

Rule 1: If all possible coordinate points of the zone Tie outside the given conic surface, the sign of $\mathrm{J}$ is negative.

Rule 2: If all possible coordinate points of a zone lie inside the given conic surface, the sign of $J$ is positive.

\section{Rules for Planar Boundary Functions}

The rules for the planes are the same whether they are perpendicular to the $x-, y-$, or $z$-axis; the rules will be explained by using planes perpendicular to the $z$-axis. 
INPUT CARD 6 (cont.)

\begin{tabular}{|c|c|c|}
\hline Columns & Name & Description \\
\hline \multirow[t]{4}{*}{$\begin{array}{l}1-72 \\
\text { (cont.) }\end{array}$} & JZOND & $\begin{array}{l}\text { Rule 1: If all z-coordinates in the zone are algebra- } \\
\text { ically greater than the plane intercept with the } z \text {-axis, } \\
J \text { is negative. }\end{array}$ \\
\hline & & $\begin{array}{l}\text { Rule 2: If all z-coordinates in the zone are algebra- } \\
\text { ically less than the plane intercept with the } z \text {-axis, J } \\
\text { is positive. }\end{array}$ \\
\hline & & $\begin{array}{l}\text { These four rules allow the construction of a problem with } \\
\text { a minimum of effort. }\end{array}$ \\
\hline & & $\begin{array}{l}\text { Note: Sometimes it may be necessary to reference a plane } \\
\text { that is not actually a boundary of the zone. In this } \\
\text { instance, the value of } P \text { is not important. A given } \\
\text { boundary should never be mentioned twice in one zone } \\
\text { description. Outside zones must be described by at least } \\
\text { one boundary. }\end{array}$ \\
\hline
\end{tabular}

The rules for JPB can be pictorially represented for conics by the following figure.

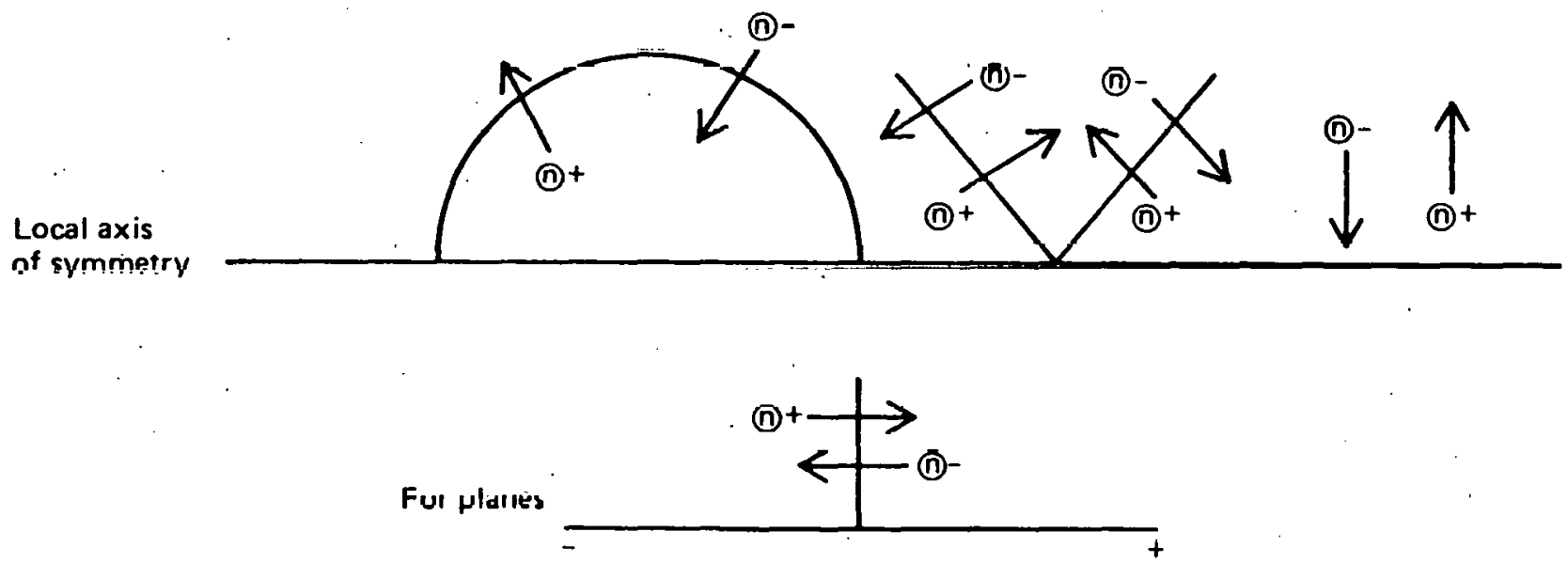


INPUT CARD 7. FUDGE, SOURCE, ANGULAR DISTRIBUTION OF SOURCE

Format (6F12.5)

\begin{tabular}{|c|c|c|}
\hline Columns & Name & Description \\
\hline $1-12$ & FUDGE & $\begin{array}{l}\text { This is the amount added to the distance a particle is } \\
\text { advanced to a boundary to ensure that it will be in a new } \\
\text { zone. A value of } 0.0005 \text { is typical for normal size } \\
\text { problems. If this entry is left blank, it is set to } \\
0.0005 \text {. }\end{array}$ \\
\hline $13-24$ & $X N$ & S3. Input for source description. See name S1 in Card 2. \\
\hline $25-36$ & YN & S4. See $\$ 1$ in Card 2 . \\
\hline $37-48$ & $\mathrm{ZN}$ & S5. See S1 in Card 2. \\
\hline $49-60$ & GPPP & $\begin{array}{l}\text { S6. The angular distribution of the source is such that } \\
\text { the cosine of the angle between the particle and a } \\
\text { reference direction is uniformly distributed in the } \\
\text { interval ( } S 7, S 6+S 7) \text {; that is, the cosine is computed } \\
\text { from } S 6 * R+S 7 \text {, where } R \text { is a random number between } 0 \text { and } \\
1 \text {. The azimuthal angle is uniformly distributed in the } \\
\text { interval }(0,2 \pi) \text {. The reference direction is the positive } \\
z \text {-axis, except when } S 1=6,7 \text {, or } 8 \text {. An isotropic source } \\
\text { is obtained by setting } S 6=2.0 \text { and } S 7=-1.0 \text {. A source } \\
\text { beamed in the positive direction down the } z-a x i s \text { is } \\
\text { obtained by setting } S 6=0.0 \text { and } S 7=1.0 \text {. }\end{array}$ \\
\hline $61-72$ & GPXP & S7. \\
\hline
\end{tabular}

INPUT CARD 8. SUURCE ENERGY, NUMBER OF PAIRS IN SPECTRUM, OTHER SOURCE, Format $(6 \mathrm{~F} 12.5)$

\begin{tabular}{|c|c|c|}
\hline Columns & Name. & Description \\
\hline $1-12$ & VN & $\begin{array}{l}\text { Source energy in MeV. A positive entry will.give a } \\
\text { monoenergetic source. at the. indicated value. A zero } \\
\text { entry will give a fission source. A negative entry } \\
\text { indicates that it will. be chosen from an energy spectrum } \\
\text { made of that many pairs of points, or from that many } \\
\text { energy-angle pairs if ISPEC }=11 \text {, or from that many } \\
\text { different energy spectra if. ISPEC }=12 \text {. }\end{array}$ \\
\hline $13-72$ & & S8, S9, S10, S11, S12. See S1 in Card 2. \\
\hline
\end{tabular}


INPUT CARD 9. MINIMUM ENERGY, INITIAL TIME, SOURCE DATA Format (6F12.5)

\begin{tabular}{|c|c|c|}
\hline Columns & Name & Description \\
\hline $1-12$ & VMIN & $\begin{array}{l}\text { Minimum energy in MeV for neutrons. If a positive value } \\
\text { is entered, this is the minimum value a scattered neutron } \\
\text { may have. If a negative value is entered and a neutron } \\
\text { scatters below this value, the neutron is discarded. The } \\
\text { number discarded is tallied under velocity gain in the } \\
\text { output. If this entry is left blank, the code enters } \\
2.51 \times 10-8 \text { as VMIN. }\end{array}$ \\
\hline $13-24$ & TN & $\begin{array}{l}\text { Initial time coordinate. If the "type of time distribu- } \\
\text { tion" has a value of } 0 \text { or } 1 \text {, all surce particles will } \\
\text { ladve this value as their initial time coordinate. } \\
\text { Negative times are not allowed. }\end{array}$ \\
\hline $25-36$ & $\$ 13$ & $\begin{array}{l}\text { Emin for Tally. Type } 11 \text { or } 12 \text {. No particles will be } \\
\text { written on tape if they are below this energy. If this } \\
\text { entry is left blank, } 2.5 \times 10^{-8} \text { is entered. }\end{array}$ \\
\hline $37-48$ & $\$ 14$ & $\begin{array}{l}\text { Temperature of Maxwellian distribution used for input } \\
\text { energy spectrum. If this entry is left blank, the code } \\
\text { asșumes a value of } 1.29 \text {. }\end{array}$ \\
\hline $49-60$ & S15 & See S1 in Card 2. \\
\hline $61-72$ & S16 & $\begin{array}{l}\text { Emax for Tally Type } 11 \text { or } 12 \text {. No particles above this } \\
\text { energy will be written on tape. If lhis entry is left } \\
\text { blank, } 20 \mathrm{MeV} \text { is entered. }\end{array}$ \\
\hline
\end{tabular}

INPUT CARD 9A. CHANGE CUSINE LIMITS FUR: NEUIRUN-ANGULAR-UISTRIBUTION TALLIES (optional) Format $(6 \mathrm{~F} 12.5)$

\begin{tabular}{|c|c|c|}
\hline Columns & Name & Description \\
\hline $1-72$ & ANGLI & $\begin{array}{l}\text { Enter ITX (Card } 2 \text {, Columns } 61-64) \text { cosine values starting } \\
\text { with plus } 1.0 \text { and mumulunically decreasing to minus } 1.0 \text {. } \\
\text { The cosine values are truncated to the least one-hundredth } \\
(\mathrm{e} . \mathrm{g} ., 0.9899=0.98) \text {. }\end{array}$ \\
\hline
\end{tabular}

INPUT CARD 9B. CHANGE COSINE LIMITS FOR PHOTON-ANGULAR-DISTRIBUTION TALLIES (optional) Format (6F12.5)

\begin{tabular}{lll}
\hline Columns & Name & Description \\
\hline $1-72$ & $\begin{array}{l}\text { Enter ITXG (Card 3B, Columns 21-24) cosine values. The } \\
\text { values are truncated to the least one-hundredth (e.g., } \\
0.9899=0.98) .\end{array}$ \\
\hline
\end{tabular}


INPUT CARD 10. CONIC SURFACE BOUNDARY FUNCTION

Format $(5 F 12.5,2 F 10.3)$

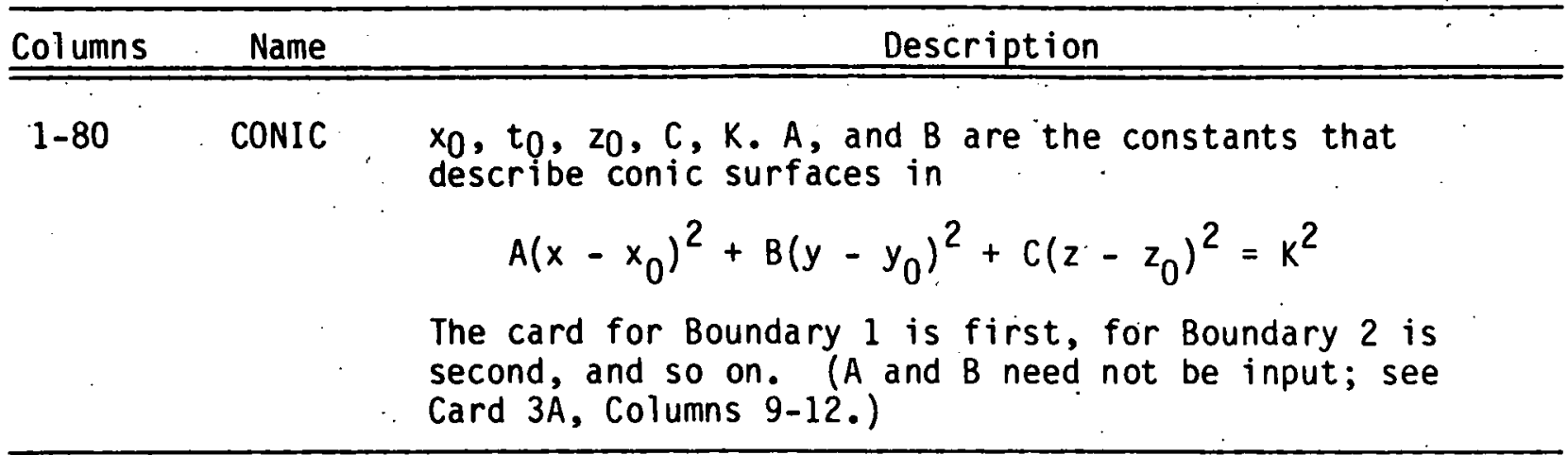

INPUT CARD 11. PLANES Format (6F12.5)

\begin{tabular}{|c|c|c|}
\hline Columns & Name & Description \\
\hline $1-72$ & PLANE & $\begin{array}{l}\text { M for planes. The constants } M \text { are intercepts of the axes } \\
\text { for the plane boundaries. The constants for planes } \\
\text { perpendicular to the } x \text {-axis are listed first, those for } \\
\text { planes perpendicular to the } z \text {-axis are listed last. The } \\
\text { plane boundaries are numbered according to the order of } \\
\text { the constants: the first is }-1 \text {, the second is }-2 \text {, and so } \\
\text { on. There are six.planes to a card. }\end{array}$ \\
\hline
\end{tabular}

INPUT CARD 12. MATERIAL IN A ZONE, STATISTICAL WEIGHT, TALLY TYPE UNITS Format (F9.0, I3, 3F12.5, F6.0, 213, F12.5)

\begin{tabular}{ccl}
\hline Columns & Name & Description \\
\hline $1-9$ & WGTGAM & $\begin{array}{l}\text { Zonal statistical weight for photons, See description of } \\
\text { weight on Card 12, Column } 13-24 . \text { If this entry is left } \\
\text { blank, the weight assigned to neutrons will be entered. }\end{array}$ \\
$10-12 . \quad$ NDAT4 & $\begin{array}{l}\text { Material in a zone. This is the number of the material } \\
\text { asigned to each zone. The card for Zone } 1 \text { is first, that } \\
\text { for Zone } 2 \text { is second, and so on. This material-in-a-zone } \\
\text { card is required for each inside zone. (If zero is } \\
\text { entered, the zone becomes a leakage zone.) This number } \\
\text { is in a fixed format; that is, it is right-adjusted to } \\
\text { column } 12 .\end{array}$
\end{tabular}


INPUT CARD 12 (cont.)

\begin{tabular}{|c|c|c|}
\hline Columns & Name. & Description \\
\hline $13-24$ & WGT & $\begin{array}{l}\text { Zonal statistical weight for neutrons. Weights other } \\
\text { than } 1.0 \text { are used in high-attenuation problems to force } \\
\text { particle flow into regions of interest. Weights must be } \\
\text { powers of } 2 \text {, and ratios of weights of adjacent zones must } \\
\text { be } 1 / 2,1 \text {, or } 2 \text {. The product of weight and number of } \\
\text { particles is conserved at a boundary crossing. For } \\
\text { example, if a particle crosses from a high-weight zone to } \\
\text { a low-weight zone, the particle is split into two } \\
\text { particles. If a particle crosses from a low-weight zone } \\
\text { into a high-weight zone, the particle is discarded with } \\
\text { probability } 1 / 2 \text {. If the weight is left blark, il is } \\
\text { assumed to be } 1.0 \text {. }\end{array}$ \\
\hline $25-36$ & ETA & $\begin{array}{l}\text { Relative density. This is the ratio of the density of } \\
\text { the material in the zone to the density used in the } \\
\text { material input. If this entry is lett blank, the code } \\
\text { enters a } 1.0 \text {. }\end{array}$ \\
\hline $37-48$ & VOFL & $\begin{array}{l}\text { Minilimim energy for neutrons in a zone. Zones that are } \\
\text { not assigned a value here are assumed to have the value } \\
\text { of VMIN. See Card } 9 \text {, Columns } 1-12 \text {, or description. }\end{array}$ \\
\hline $49-54$ & EMING & $\begin{array}{l}\text { Minimum energy for photons in a zone. Zones that are not } \\
\text { assigned a value here are assumed to have the value of } \\
\text { EMIN from Card } 3 B \text {, Columns } 1-12 \text {. }\end{array}$ \\
\hline $55-57$ & LTYPEG & $\begin{array}{l}\text { Photon edit indicator. Each zone may have a separate } \\
\text { photon tally type. If this entry is left blank, ITNG, } \\
\text { Card } 3 \dot{B} \text {, columns } 13-16 \text {, is iriserled. }\end{array}$ \\
\hline $58-60$ & LTYPE & $\begin{array}{l}\text { Neutron edit indicator. LTYPE allows each zone to have } \\
\text { one of the tally types listed for ITN, Card } 2 \text {, } \\
\text { Columns } 49-52 \text {, with the same limitation as described. If } \\
\text { this entry is left blank, ITN is inserted. }\end{array}$ \\
\hline $61-72$ & UNITS & $\begin{array}{l}\text { Zone multiplier. In addition to standard output, a } \\
\text { constant can be entered rui each zone to modify the } \\
\text { output to different units. (See discussion after the } \\
\text { listing of the options for ITN, Card 2, Columns 49-52.) }\end{array}$ \\
\hline
\end{tabular}


INPUT CARD 12A. GEOMETRICAL DEBUG PARAMETERS (optional)

Format .(I12, 4F12.5)

\begin{tabular}{|c|c|c|}
\hline Columns & Name & Description \\
\hline $1-60$ & . & $\begin{array}{l}\text { If the debug sentinel (Card } 3 A \text {, Column } 36 \text { ) is set to } 1 \text {, a } \\
\text { geometric volume of the problem defined by Cards } 12 \mathrm{~A} \text { and } \\
12 \mathrm{~B} \text { will be saturated with particles in order to determine } \\
\text { whether any space is not properly described. Any errors } \\
\text { found will be printed out. If there are too many errors, } \\
\text { the problem will be terminated. Statistical volumes will } \\
\text { also be calculated for those zones that are bounded by } \\
\text { three-dimensional boundaries. The values for ICOOD, etc., } \\
\text { given on Cards } 12 \mathrm{~A} \text { and } 12 \mathrm{~B} \text { have nothing to do with the } \\
\text { source input for the problem but are used for the } \\
\text { generator-debug routine only. The volume of the problem } \\
\text { to be examined can be either cylindrical, spherical, or } \\
\text { rectangular. }\end{array}$ \\
\hline 12 & ICOOD & $\begin{array}{l}\text { ICOOD }=2,3 \text {, or } 5 \text { for cylindrical, spherical, or } \\
\text { rectangular volume (defined as S1, Card } 2 \text { ). }\end{array}$ \\
\hline $13-24$ & FRAC & $\begin{array}{l}\text { The number of particles per cubic centimeter used to } \\
\text { saturate the given volume. Note that a } 50-\text {-zone problem } \\
\text { with a volume of } 1.5 \times 10^{5} \mathrm{~cm}^{3} \text { takes about. } 1 \text { min of } \\
\text { computer time to test } 1.5 \times 10^{5} \text { particles and calculates } \\
\text { volumes to about } \pm 10 \% .\end{array}$ \\
\hline $25-60$ & & $\begin{array}{l}\text { RA, RB, Z1. Used to define the volume. Equivalent to } \\
\text { input parameters } S 3, S 4 \text {, and } S 5 \text { (see } S 1 \text {, Card } 2 \text { ). }\end{array}$ \\
\hline
\end{tabular}

INPUT CARD 12B. CONTINUATION OF CARD 12A (optional)

Format (6F12.5)

\begin{tabular}{lll}
\hline Columns & Name & Description \\
\hline $1-72$ & SA, Z3, X0, Y0, SA2, S51. Used to define the volume. \\
& $\begin{array}{l}\text { Equivalent to input parameters S8, S9, S10, S11, S12, and } \\
\text { S15 (see S1, Card 2). }\end{array}$ \\
\hline
\end{tabular}




\begin{tabular}{|c|c|c|}
\hline Columns & Name & Description \\
\hline $1-60$ & TL & $\begin{array}{l}\text { Time distribution table. If entry for "type of time } \\
\text { distribution" (Card } 2 \text {, Columns } 53-56 \text { ) is } 2 \text { or greater, } \\
\text { this card is used. The number of times equal to that } \\
\text { entry is entered, six at a time, to a maximum of } 12 \text {. The } \\
\text { time coordinate is sampled in such a way that the initial } \\
\text { time coordinate is chosen with equal probability from } \\
\text { each interval and is chosen uniformly within the interval. } \\
\text { Time is in shakes }(10-8 \mathrm{~s}) \text {. If ITM (Card } 2 \text {, Columns } 53- \\
56 \text { ) is negative, then that many pairs of points } N(T) \text { and } \\
T \text { will be entered (three pairs of points to a card, up to } \\
\text { a maximum of luo pairs). N( }(1) \text { is in particles per shake } \\
\text { and T is in shakes. This is not a histogram. The code } \\
\text { assumes that consecutive pairs of points are connected by } \\
\text { a straight line of the form AT + B, and it integrates } \\
\text { over time to obtain the number of particles in each } \\
\text { interval. }\end{array}$ \\
\hline
\end{tabular}

INPUT CARD 15. EDIT TIMES

Format (5F12..5)

\begin{tabular}{lll}
\hline Columns & Name & Description \\
1-60 TCT & $\begin{array}{l}\text { Times at which edits are taken. The various output } \\
\text { quantities are accumulated up to the edit times. A } \\
\text { maximum of five is allowed. Time is in shakes. }\end{array}$
\end{tabular}

INPUT CARD CARD 15A. ENERGY-DEPENDENT NEUTRON OUTPUT TALLY MULTIPLIERS (OPTIONAL) Format (6F12.5)

\begin{tabular}{lll}
\hline Columns Name & \multicolumn{1}{c}{ Descriptinn } \\
\hline $1-72$ & EDIF & $\begin{array}{l}\text { If IEDIF (Card 3, Columns 9-12) is equal to 2, } 50 \text { numbers } \\
\text { are read in to be used as tally group multipliers for the } \\
\text { output by energy. }\end{array}$ \\
\hline
\end{tabular}

INPUT CARD 15B. ENERGY-DEPENDENT PHOTON OUTPUT TALLY MULTIPLIERS (OPTIONAL) Format (6F12.5)

\begin{tabular}{lll}
\hline Columns & Name & Description \\
\hline $1-72$ & EDIG & $\begin{array}{l}\text { If IGSENT (Card 3B, columns 29-32) is equal to 2, 50 } \\
\text { numbers are read in to be used as tally group multipliers } \\
\text { for the photon output by energy. }\end{array}$ \\
\hline
\end{tabular}


INPUT CARD 16. ENERGY SPECTRUM (OPTIONAL)

Format (6F12.5)

\begin{tabular}{lll}
\hline Columns & Name & Description \\
\hline $1-72$ & FNS & $\begin{array}{l}\text { If the entry on Card } 8 \text {, Columns 1-12, is zero or positive, } \\
\text { or if ISPEC (Card 3, Columns 1-4) is 11 or 12, this card } \\
\text { should be omitted. }\end{array}$ \\
& $\begin{array}{l}\text { If the entry on Card 3, Columns 1-4, is 1, this table } \\
\text { will consist of pairs of entries } N(E) \text { and E, where E is } \\
\text { in MeV. There are IVNI (Card 8, Columns 1-12) of these } \\
\text { pairs. }\end{array}$
\end{tabular}

INPUT CARD 17. ENERGY-ANGLE-CORRELATED SOURCE WITH ANGULAR-DISTRIBUTION WEIGHTING FUNCTION (OPTIONAL) Format (6F12.5)

\begin{tabular}{lll}
\hline Columns - & Name & Description \\
\hline $1-72$ & FNS & $\begin{array}{l}\text { Input array for angle of source. If ISPEC (Card 3, } \\
\text { Columns } 1-4) \text { is } 11, \text { then }|V N| \text { (Card } 8 \text {, Columns 1-12) } \\
\text { pairs of entries of } N(Y) \text { and } \gamma \text { make up this table. The } \\
\text { entries should range from }-1.0 \text { to }+1.0 .\end{array}$ \\
\hline
\end{tabular}

INPUT CARD 17A. ENERGY-ANGLE-CORRELATED SOURCE WITH ANGULAR-DISTRIBUTION WEIGHTING FUNCTION (OPTIONAL) Format (I4)

\begin{tabular}{lll}
\hline Columns & Name & Description \\
\hline $1-4$ & $K 2$ & $\begin{array}{l}\text { Number of energy-angle pairs. If ISPEC (Card 3, } \\
\text { Columns 1-4) is 11, this entry is the number of pairs of } \\
\text { energy and angle to be entered on Card 17B. }\end{array}$ \\
\hline
\end{tabular}

INPUT CARD 17B. ENERGY-ANGLE-CORRELATED SOURCE WITH ANGULAR-DISTRIBUTION WE IGHTING FUNCTION (OPTIONAL) Format (6F12.5)

\begin{tabular}{|c|c|c|}
\hline Cólumins & Name & Description \\
\hline $1-72$ & FNS & $\begin{array}{l}\text { Energy-angle table. If ISPEC is } 11, \text { K2 pairs of data } \\
\left.\left[E_{1}, \gamma_{1}\right] \ldots \text { [ [ } E_{K 2}, \gamma_{K 2}\right] \text { are entered. Values of } \gamma \\
\text { should range from }-1.0 \text { to }+1.0 \text {, but they do not have to } \\
\text { be the same as on Card } 17 \text {. }\end{array}$ \\
\hline
\end{tabular}


INPUT CARD 17C. MULTIPLE-ANGLE ENERGY SPECTRA (OPTIONAL)

Format $(2 \mathrm{I} 12,2 \mathrm{~F} 12.5)$

\begin{tabular}{|c|c|c|}
\hline Columns & Name & Description \\
\hline $1-48$ & & $\begin{array}{l}\text { Multiple-angle energy spectra control. If ISPEC (Card } 3 \text {, } \\
\text { Columns } 1-4 \text { ) is } 12 \text {, there will be |VN| (Card } 8 \text {, } \\
\text { Columns } 1-12 \text { ) } 17 \mathrm{C} \text { cards. Each } 17 \mathrm{C} \text { card will be followed } \\
\text { by as many } 170 \text { cards as necessary. }\end{array}$ \\
\hline $1-12$ & ISOU & Relative number of particles in this spectrum. \\
\hline $13-24$ & NUMB & $\begin{array}{l}\text { Number of pairs of points } N(E) \text { and } E \text { to be entered on } \\
\text { Card } 170 \text { (maximum of } 100) \text {. }\end{array}$ \\
\hline $\begin{array}{l}25-36 \\
37-48\end{array}$ & $\begin{array}{l}\cos 1 \\
\cos 2\end{array}$ & $\begin{array}{l}\text { COS1 and COS2 are the limits of cos } \gamma \text { between which this } \\
\text { spectrum will be generated. If S1 (Card } 2 \text {, Columns } 37-40 \text { ) } \\
\text { is } 13 \text {, the angles } r \text { will be measured from the normal to a } \\
\text { spherical surface at the point of generation. 0therwise } \\
\text { the angles are measured with respect to the z-axis. }\end{array}$ \\
\hline
\end{tabular}

INPUT CARD 170. MULTIPLE-ANGLE ENERGY SPECTRA (OPTIONAL) Format (6F12.5)

\begin{tabular}{lll}
\hline Columns & Name & Description \\
\hline $1-72$ & FNS & $\begin{array}{l}\text { Energy array. Number (Card } 17 C, C o l u m n s ~ 13-24) \text { of pairs } \\
\text { of entries of } N(E) \text { and } E, \text { where } N(E) \text { is the number of } \\
\text { particles per unit energy } E \text { (in MeV). There are three. } \\
\text { pairs to a card. tvery } 1 / C \text { card wili be followed by as } \\
\text { inany } 170 \text { cards as are necessary. }\end{array}$ \\
\hline
\end{tabular}

INPUT CARD 18. ISOTOPIC COMPOSITION OF MATERIAI.S

Format (2I3, F10.3, 4(F8.6, I6))

Columns Name Description

$\begin{array}{lll}1-3 & M & \begin{array}{l}\text { Material number. Materials must be numbered in } \\ \text { consecutive order. }\end{array} \\ 4-6 & \text { ISUBM } & \text { Number of isotopes in the material. } \\ 7-16 & \text { XISUBM } & \text { Density of the material in grams per cubic centimeter. } \\ 17-24 & \text { XISUBM Atom fraction of first isotope in the material. }\end{array}$


INPUT CARD 18 (cont.)

\begin{tabular}{|c|c|c|}
\hline Columns & Name & Description \\
\hline $25-30$ & ISUBM & ZA of the first isotope in the material (ZZZAAA). \\
\hline $31-38$ & XISUBM & Fraction of the second isotope. \\
\hline \multirow[t]{2}{*}{$39-44$} & ISUBM & ZA of the second isotope, etc. \\
\hline & INPUT & $\begin{array}{l}\text { CARD 19. ISOTOPIC COMPOSITION OF MATERIALS } \\
\text { Format }(16 \mathrm{X}, 4(\mathrm{~F} 8.6, \text { I6) })\end{array}$ \\
\hline Columns & Name & Description \\
\hline $1-72$ & & $\begin{array}{l}\text { This card is to be used if the number of isotopes in a } \\
\text { material is greater than } 4 \text {. }\end{array}$ \\
\hline $1-16$ & & Not used. \\
\hline $17-24$ & XISUBM & Fraction of fifth (or multiple of fifth) isotope. \\
\hline \multirow[t]{2}{*}{$25-30$} & ISUBM & Fifth (or multiple of fifth) isotope, etc. \\
\hline & INPUT & $\begin{array}{l}\text { CARD 19A. PROBLEM MULTIPLIERS (OPTIONAL) } \\
\text { Format }(5 F 12.5)\end{array}$ \\
\hline Columns & Name & Description \\
\hline $1-60$ & PROBM & $\begin{array}{l}\text { Problem multipliers. If I13 (Card } 3 \text {, Columns } 41-44 \text { ) is } \\
\text { nonzero, II3 problem multipliers are entered. The } \\
\text { energy deposited. (expressed in MeV/g or MeV/ } / \mathrm{cm}^{3} \text { ) and } \\
\text { fissions (expressed as number of fissions per gram or } \\
\text { cubic cent imeter) by zone and time step are multiplied by } \\
\text { these conversion factors. (See Card 2, Columns } 49-52 \text {, and } \\
\text { IA23, IA24, Card 3A, Columns 37-44.) }\end{array}$ \\
\hline
\end{tabular}

INPUT CARD 20. MULTIPLE SHELLS; CYLINDRICAL OR SPHERICAL (OPTIONAL) Format $(12,10 \mathrm{~F} 7.0)$

\begin{tabular}{lll}
\hline Columns & Name & Description \\
\hline $1-72$ & & Used only when S1 is 9,10 , or 11 (Card 2, Columns 37-40). \\
$1-2$ & LSOR & Number of source shells (maximum of 15). \\
$3-72$ & SOURC & Relative number of particles in each shell (Format 10F7.0). \\
\hline
\end{tabular}


INPUT CARD 21. MULTIPLE SHELLS (CYLINDRICAL OR SPHERICAL) (OPTIONAL) Format (6F12.5, F8.1)

\begin{tabular}{|c|c|c|}
\hline Columns & Name & Description \\
\hline $1-80$ & & $\begin{array}{l}\text { Used only when S1 is } 9 \text { or } 10 \text {. There will be LSOR } \\
\text { (Card } 20 \text {, Columns } 1-2 \text { ) of these cards. . }\end{array}$ \\
\hline $1-12$ & RI & Innei radius. \\
\hline $13-24$ & RO & Outer radius. \\
\hline $25-26$ & XOV & Displacement of center on x-axis. \\
\hline $37-48$ & YOV & Displacement of center on $y$-axis. \\
\hline $49-60$ & ZOV & Displacement of center on z-axis. \\
\hline $61-72$ & ZDEL & Length of cylinder (for $S 1=10$ only). \\
\hline $73-80$ & TIM & Initial time coordinate. \\
\hline
\end{tabular}

INPUT CARD 22. SURFACE SOURCE (OPTIONAL)

Format (2I3, 6E11.4)

\begin{tabular}{|c|c|c|}
\hline Con] uımns & Name & Description \\
\hline $1-72$ & 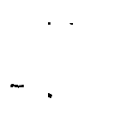 & $\begin{array}{l}\text { Boundary data for source } S 1=11 \text {. If } S 1=11 \text {, the number } \\
\text { of these cards will be LSOR (Card } 20 \text {, Columns } 1-2) \text {. }\end{array}$ \\
\hline $1-3$ & $I:$ & $\begin{array}{l}\text { Type of surface on which source is generated. } \\
I=1: \text { conic surface. } \\
\frac{I=2}{I=3}: \text { sphere. } \\
I=4: \text { cylinder. }\end{array}$ \\
\hline $4-6$ & L & Probable zone in which source is generated. \\
\hline $7-17$ & RI & Z1 for a conic source and R for other sources. \\
\hline $18-28$ & RO & $\begin{array}{l}\text { Z2 for a conic source. A2 for sphere (the segment } \\
\text { of sphere generated is defined by } A 1 * R+A 2) . Z 2 \text { for } \\
\text { cylinder. R0 for disk. }\end{array}$ \\
\hline $29-3 y$ & $x 0$ & xo for all sources. \\
\hline $40-50$ & Y0 & yo for all sources. \\
\hline $51-61$ & $\mathrm{ZO}$ & Z0 for all sources. \\
\hline
\end{tabular}


INPUT CARD 22 (cont.)

\begin{tabular}{lll}
\hline Column & Name & Description \\
\hline $62-72$ & $Z$ & $\begin{array}{l}-(\text { slope }) \star \star 2 \text { for a conic source. Al for sphere. } Z 1 \text { for } \\
\text { cylinder }+1 . \text { for disk, indicating the direction of the } \\
\text { normal to the surface }(-1 \text {. for a source beamed in the } \\
\text { positive direction, }+1 \text {. for a source beamed in the } \\
\text { negative direction). }\end{array}$ \\
\hline
\end{tabular}

INPUT CARD 23. SOURCE INFORMATION FOR TALLY TYPES 18 AND 19 (OPTIONAL) Format (5F12.5)

\begin{tabular}{|c|c|c|}
\hline Columns & Name & Description \\
\hline $1-60$ & & Input for Tally Types 18 and 19. \\
\hline $1-12$ & RMAXI & Radius of disk or spherical segment. \\
\hline $13-24$ & ZIN & The z-coordinate of disk or 20 for a spherical segment. \\
\hline $25-36$ & LIN19 & Zone in which disk is generated. \\
\hline $37-48$ & KIN & Number of particles to be created. \\
\hline $49-60$ & NGI & $\begin{array}{l}\text { All zones greater than or equal to NGI will be normalized } \\
\text { by KIN. }\end{array}$ \\
\hline
\end{tabular}

INPUT CARD 24. SOURCE INFORMATION FOR TALLY TYPES 18 AND 19 (OPTIONAL) Format (5F12.5)

\begin{tabular}{|c|c|c|}
\hline Columns & Name & Description \\
\hline $1-60$ & & Input for Tally Types 18 and 19 . \\
\hline $1-12$ & MSPRS & $\begin{array}{l}\text { If } M S P R S=1 \text {, source will be put on a cylindrical disk. } \\
\text { If } M S P R S=2, \text { source will be on a spherical segment. }\end{array}$ \\
\hline $13-24$ & SPXO & Displacement on $x$-axis for spherical sgment. \\
\hline $25-36$ & SPYO & Displacement of $y$-axis for a spherical segment. \\
\hline $37-48$ & GSPH & The spherical segment is derived by $G S P H \star R+G S P H I=$ \\
\hline $49-60$ & GSPH1 & $\begin{array}{l}\cos \theta \text {, where } \cos \theta \text { is relative to the } z \text {-axis and } R \text { is } a \\
\text { random number. }\end{array}$ \\
\hline
\end{tabular}




\section{APPENDIX A--LIST OF AVAILABLE ISOTOPES}

$\begin{array}{rl}1 & 0-n u-1 \\ 1001 & 1-h-1 \\ 1002 & 1-h-2 \\ 1003 & 1-h-3 \\ 2003 & 2-h e-3 \\ 2004 & 2-h e-4 \\ 3006 & 3-1 i-6 \\ 3007 & 3-1 i-7 \\ 4007 & 4-b e-7 \\ 4009 & 4-b e-9 \\ 5010 & 5-b-10 \\ 5011 & 5-b-11 \\ 6012 & 6-c-12 \\ 7014 & 7-n-14 \\ 8016 & 8-0-16 \\ 9019 & 9-f-19 \\ 11023 & 11-n a-23 \\ 12000 & 12-m g-n a t \\ 13027 & 13-a 1-27 \\ 14000 & 14-\text { si-nat } \\ 15031 & 15-p-31 \\ 16032 & 16-s-32 \\ 17000 & 17-c 1-\text { nat } \\ 18000 & 18-a r-n a t \\ 19000 & 19-k-n a t \\ 20000 & 20-c a-n a t \\ 22000 & 22-t i-n a t \\ 23051 & 23-v-51 \\ 24000 & 24-c r-n a t \\ 25055 & 25-m n-55\end{array}$

$\begin{array}{ll}26000 & 26-\text { fe-nat } \\ 27059 & 27-\text { co-59 } \\ 28000 & 28-n i-n a t \\ 28058 & 28-n i-58 \\ 29000 & 29-c u-n a t \\ 31000 & 31-\text { ga-nat } \\ 40000 & 40-\text { zr-nat } \\ 41093 & 41-\text { nb-93 } \\ 42000 & 42-\text { mo-nat } \\ 47107 & 47-\text { ag-107 } \\ 47109 & 47-\text { ag-109 } \\ 48000 & 48-\text { cd-nat } \\ 50000 & 50-\text { sn-nat } \\ 56138 & 56-\text { ba-138 } \\ 63000 & 63-\text { eu-nat } \\ 64000 & 64-\text { gd-nat } \\ 67165 & 67-\text { ho-165 } \\ 73181 & 73-\text { ta-181 } \\ 74000 & 74-w-\text { nat } \\ 75185 & 75-\text { re-185 } \\ 75187 & 75-\text { re-187 } \\ 78000 & 78-\text { pt }- \text { nat } \\ 79197 & 79-\text { au-197 } \\ 82000 & 82-\text { pb-nat } \\ 90231 & 90-\text { th- } 231 \\ 90232 & 90-\text { th-232 } \\ 90233 & 90-\text { th-233 } \\ 92233 & 92-u-233 \\ 92234 & 92-u-234 \\ 92235 & 92-u-235\end{array}$

$\begin{array}{ll}92236 & 92-u-236 \\ 92237 & 92-u-237 \\ 92238 & 92-u-238 \\ 92239 & 92-u-239 \\ 92240 & 92-u-240 \\ 93237 & 93-\mathrm{np}-237 \\ 94238 & 94-\mathrm{pu}-238 \\ 94239 & 94-\mathrm{pu}-239 \\ 94240 & 94-\mathrm{pu}-240 \\ 94241 & 94-\mathrm{pu}-241 \\ 94242 & 94-\mathrm{pu}-242 \\ 94243 & 94-\mathrm{pu}-243 \\ 95241 & 95-\mathrm{am}-241 \\ 95242 & 95-\mathrm{am}-242 \\ 95243 & 95-\mathrm{am}-243 \\ 96242 & 96-\mathrm{cm}-242 \\ 96243 & 96-\mathrm{cm}-243 \\ 96244 & 96-\mathrm{cm}-244 \\ 96245 & 96-\mathrm{cm}-245 \\ 96246 & 96-\mathrm{cm}-246 \\ 96247 & 96-\mathrm{cm}-247 \\ 96248 & 96-\mathrm{cm}-248 \\ 97249 & 97-\mathrm{bk}-249 \\ 98249 & 98-\mathrm{cf}-249 \\ 98250 & 98-\mathrm{cf}-250 \\ 98251 & 98-\mathrm{cf}-251 \\ 98252 & 98-\mathrm{cf}-252 \\ 99120 & \text { fission } \\ & \text { products }\end{array}$

nat indicates the naturally occurring element. 
APPENDIX B--NEUTRON ENERGY GROUPS

\begin{tabular}{|c|c|}
\hline $\begin{array}{l}1.307 e-09 \\
5.227 e-09 \\
2.091 e-08 \\
3.267 e-08 \\
4.704 e-08 \\
8.322 e-08 \\
1.307 e-07 \\
1.882 e-07 \\
2.561 e-07 \\
3.345 e-07 \\
4.234 e-07 \\
5.123 e-07 \\
7.527 e-07 \\
1.176 e-06 \\
1.511 e-06 \\
2.091 e-06 \\
2.741 e-06 \\
3.533 e-06 \\
4.704 e-06 \\
5.658 e-06 \\
6.737 e-06 \\
8.322 e-06 \\
9.620 e-06 \\
1.101 e-05 \\
1.307 e-05 \\
1.468 e-05 \\
1.581 e-05 \\
1.758 e-05 \\
1.882 e-05 \\
2.075 e-05 \\
2.277 e-05 \\
2.417 e-05 \\
2.561 e-05 \\
2.710 e-05 \\
2.862 e-05\end{array}$ & $\begin{array}{ll}36 & 2.940 \mathrm{e}-05 \\
37 & 3.099 \mathrm{e}-05 \\
38 & 3.345 \mathrm{e}-05 \\
39 & 3.601 \mathrm{e}-05 \\
40 & 3.866 \mathrm{e}-05 \\
41 & 4.048 \mathrm{e}-05 \\
42 & 4.234 \mathrm{e}-05 \\
43 & 4.329 \mathrm{e}-05 \\
44 & 4.619 \mathrm{e}-05 \\
45 & 4.717 \mathrm{e}-05 \\
46 & 4.918 \mathrm{e}-05 \\
47 & 5.123 \mathrm{e}-05 \\
48 & 5.332 \mathrm{e}-05 \\
49 & 5.654 \mathrm{e}-05 \\
50 & 5.763 \mathrm{e}-05 \\
51 & 6.097 \mathrm{e}-05 \\
52 & 6.325 \mathrm{e}-05 \\
53 & 6.557 \mathrm{e}-05 \\
54 & 6.674 \mathrm{e}-05 \\
55 & 7.034 \mathrm{e}-05 \\
56 & 7.155 \mathrm{e}-05 \\
57 & 7.527 \mathrm{e}-05 \\
58 & 7.780 \mathrm{e}-05 \\
59 & 7.908 \mathrm{e}-05 \\
60 & 8.167 \mathrm{e}-05 \\
61 & 8.431 \mathrm{e}-05 \\
62 & 8.834 \mathrm{e}-05 \\
63 & 9.108 \mathrm{e}-05 \\
64 & 9.386 \mathrm{e}-05 \\
65 & 9.668 \mathrm{e}-05 \\
66 & 9.811 \mathrm{e}-05 \\
67 & 1.025 \mathrm{e}-04 \\
68 & 1.099 \mathrm{e}-04 \\
69 & 1.176 \mathrm{e}-04 \\
70 & 1.256 \mathrm{e}-04\end{array}$ \\
\hline
\end{tabular}

$71 \quad 1.338 \mathrm{e}-04$

$721.406 \mathrm{e}-04$

$731.511 \mathrm{e}-04$

$741.601 \mathrm{e}-04$

$751.694 \mathrm{e}-04$

$761.789 \mathrm{e}-04$

$771.887 e-04$

$781.988 \mathrm{e}-04$

$792.091 \mathrm{e}-04$

$802.741 \mathrm{e}-04$

$813.267 e-04$

82 3.811e-04

$834.704 \mathrm{e}-04$

$84 \quad 4.991 \mathrm{e}-04$

$855.658 \mathrm{e}-04$

$86 \quad 6.042 \mathrm{e}-04$

$876.367 e-04$

$887.156 \mathrm{e}-04$

$898.322 \mathrm{e}-04$

$90 \quad 9.177 \mathrm{e}-04$

$911.058 \mathrm{e}-03$

$921.307 \mathrm{e}-03$

$931.581 \mathrm{e}-03$

$941.882 \mathrm{e}-03$

$952.208 \mathrm{e}-03$

96 2.561e-03

$972.940 \mathrm{e}-03$

$983.345 \mathrm{e}-03$

$993.777 \mathrm{e}-03$

$100 \quad 4.234 \mathrm{e}-03$

$1015.763 \mathrm{e}-03$

$1027.527 \mathrm{e}-03$

$1031.025 \mathrm{e}-02$

$1041.511 \mathrm{e}-02$

105 2.091e-02
$1062.646 \mathrm{e}-02$

107 3.267e-02

108 3.953e-02

109 4.704e-02

$1105.761 \mathrm{e}-02$

$1117.002 \mathrm{e}-02$

$1128.322 \mathrm{e}-02$

113 9.891e-02

$1141.307 e-01$

$1151.820 \mathrm{e}-01$

$1162.075 e-01$

$1172.417 \mathrm{e}-01$

$1182.710 \mathrm{e}-01$

$1192.940 \mathrm{e}-01$

$1203.345 \mathrm{e}-01$

$1213.777 \mathrm{e}-01$

$1224.234 \mathrm{e}-01$

$1235.123 e-01$

$1246.325 \mathrm{e}-01$

$1257.527 \mathrm{e}-01$

$1268.834 \mathrm{e}-01$

$1271.025 \mathrm{e}+00$

$1281.176 \mathrm{e}+00$

$1291.338 \mathrm{e}+00$

$1301.511 \mathrm{e}+00$

$1311.694 \mathrm{e}+00$

$1321.887 \mathrm{e}+00$

$1332.091 \mathrm{e}+00$

$1342.305 \mathrm{e}+00$

$1352.530 \mathrm{e}+00$

$1362.741 \mathrm{e}+00$

$1373.011 \mathrm{e}+00$

$1383.267 \mathrm{e}+00$

$1393.533 \mathrm{e}+00$

$1403.811 \mathrm{e}+00$
$1414.069 \mathrm{e}+00$

$1424.396 \mathrm{e}+00$

$1434.704 \mathrm{e}+00$

$1444.991 \mathrm{e}+00$

$1455.353 \mathrm{e}+00$

$1465.658 \mathrm{e}+00$

$1476.042 \mathrm{e}+00$

$1486.367 \mathrm{e}+00$

$1496.737 \mathrm{e}+00$

$1507.156 \mathrm{e}+00$

$1517.548 \mathrm{e}+00$

$1527.910 \mathrm{e}+00$

$1538.322 \mathrm{e}+00$

1548.787 e+00

$1559.177 \mathrm{e}+00$

$1569.665 \mathrm{e}+00$

$1571.012 e+01$

$1581.058 \mathrm{e}+01$

$1591.101 \mathrm{e}+01$

$1601.155 \mathrm{e}+01$

$1611.199 \mathrm{e}+01$

$1621.250 \mathrm{e}+01$

$1631.307 \mathrm{e}+01$

$1641.354 \mathrm{e}+01$

$1651.386 \mathrm{e}+01$

$1661.413 e+01$

$1671.441 \mathrm{e}+01$

$1681.468 \mathrm{e}+01$

$1691.519 \mathrm{e}+01$

$1.701 .575 \mathrm{e}+01$

$1711.633 \mathrm{e}+01$

$1721.692 \mathrm{e}+01$

$1731.752 \mathrm{e}+01$

$1741.813 \mathrm{e}+01$

$1751.875 \mathrm{e}+01$

$2.000 \mathrm{e}+01$ 
APPENDIX C--PHOTON ENERGY GROUPS

\author{
$11.000 \mathrm{e}-04$ \\ $21.089 e-04$ \\ $31.103 e-04$ \\ $41.166 \mathrm{e}-04$ \\ $51.500 \mathrm{e}-04$ \\ $62.000 \mathrm{e}-04$ \\ $72.158 \mathrm{e}-04$ \\ $82.172 \mathrm{e}-04$ \\ $92.501 e-04$ \\ $102.515 \mathrm{e}-04$ \\ $113.000 \mathrm{e}-04$ \\ $123.244 \mathrm{e}-04$ \\ 13 3.847e-04 \\ $143.881 \mathrm{e}-04$ \\ $154.000 \mathrm{e}-04$ \\ $16 \quad 4.374 \mathrm{e}-04$ \\ $17 \quad 4.390 \mathrm{e}-04$ \\ $18 \quad 5.000 \mathrm{e}-04$ \\ $195.500 \mathrm{e}-04$ \\ $205.943 e-04$ \\ $215.947 \mathrm{e}-04$ \\ $226.000 \mathrm{e}-04$ \\ $236.836 \mathrm{e}-04$ \\ $246.850 \mathrm{e}-04$ \\ $257.000 \mathrm{e}-04$ \\ $267.541 \mathrm{e}-04$ \\ $277.555 \mathrm{e}-04$ \\ $28 \quad 8.000 \mathrm{e}-04$ \\ $298.197 e-04$ \\ $308.211 \mathrm{e}-04$ \\ $319.000 \mathrm{e}-04$ \\ $321.000 \mathrm{e}-03$ \\ $331.080 \mathrm{e}-03$ \\ $34 \quad 1.140 \mathrm{e}-03$ \\ $351.360 \mathrm{e}-03$
}

$361.559 \mathrm{e}-03$

$37 \quad 1.700 \mathrm{e}-03$

$381.838 \mathrm{e}-03$

$391.910 \mathrm{e}-03$

$402.142 \mathrm{e}-03$

$412.240 \mathrm{e}-03$

42 2.410e-03

$432.470 \mathrm{e}-03$

$442.630 \mathrm{e}-03$

$45 \quad 2.750 \mathrm{e}-03$

$462.820 \mathrm{e}-03$

$472.960 \mathrm{e}-03$

$483.180 \mathrm{e}-03$

$493.547 e-03$

$503.606 \mathrm{e}-03$

$513.700 \mathrm{e}-03$

$523.828 \mathrm{e}-03$

$53 \quad 4.030 \mathrm{e}-03$

54 4.150e-03

55 4.300e-03

$56 \quad 4.496 \mathrm{e}-03$

57 4.810e-03

$585.163 e-03$

$595.467 \mathrm{e}-03$

$60 \quad 5.546 \mathrm{e}-03$

$615.934 \mathrm{e}-03$

$625.980 \mathrm{e}-03$

$636.250 \mathrm{e}-03$

$646.543 \mathrm{e}^{-}-03$

$65 \quad 6.750 \mathrm{e}-03$

66 6.980e-03

$677.113 \mathrm{e}-03$

$687.251 \mathrm{e}-03$

$697.713 \mathrm{e}-03$

$707.942 \mathrm{e}-03$
$718.180 \mathrm{e}-03$

$728.383 e-03$

$738.600 \mathrm{e}-03$

74 8.982e-03

$759.200 \mathrm{e}-03$

$769.400 \mathrm{e}-03$

$779.560 \mathrm{e}-03$

$789.660 \mathrm{e}-03$

$799.800 e-03$

80 1.001e-02

81 1.039e-02

$821.075 e-02$

$83 \mathrm{1.114e-02}$

$841.192 \mathrm{e}-02$

$851.265 \mathrm{e}-02$

$861.303 \mathrm{e}-02$

87 1.386e-02

$881.470 \mathrm{e}-02$

89 1.520e-02

$901.571 \mathrm{e}-02$

91 1.639e-02

92 1.700e-02

$931.716 \mathrm{e}-02$

94 1.806e-02

95 1.898e-02

96 1.967e-02

97 2.010e-02

98 2.095e-02

$992.175 \mathrm{e}-02$

$1002.225 \mathrm{e}-02$

$1012.312 \mathrm{e}-02$

102 2.553e-02

$1032.918 \mathrm{e}-02$

$1043.316 \mathrm{e}-02$

$1053.750 \mathrm{e}-02$
$1064.200 \mathrm{e}-02$

$1074.736 \mathrm{e}-02$

108 4.851e-02

$1095.023 e-02$

$1105.500 \mathrm{e}-02$

$1116.100 \mathrm{e}-02$

$1126.745 e-02$

$1136.746 \mathrm{e}-02$

$.1146 .951 \mathrm{e}-02$

$1157.350 \mathrm{e}-02$

$1167.835 \mathrm{e}-02$

$1178.067 \mathrm{e}-02$

118 8.552e-02

$1198.795 \mathrm{e}-02$

$1209.054 \mathrm{e}-02$

$1219.230 \mathrm{e}-02$

$1229.600 \mathrm{e}-02$

$1231.000 \mathrm{e}-01$

$1241.050 \mathrm{e}-01$

$1251.097 \mathrm{e}-01$

$1261.098 \mathrm{e}-01$

$1271.149 \mathrm{e}-01$

$1281.150 \mathrm{e}-01$

$1291.211 \mathrm{e}-01$

$1301.212 \mathrm{e}-01$

$1311.351 \mathrm{e}-01$

$1321.486 \mathrm{e}-01$

$1331.635 \mathrm{e}-01$

$1341.799 \mathrm{e}-01$

$1351.978 \mathrm{e}-01$

$1362.176 \mathrm{e}-01$

$1372.394 \mathrm{e}-01$

$1382.633 \mathrm{e}-01$

$1392.897 \mathrm{e}-01$

$1403.186 \mathrm{e}-01$
$1413.505 e-01$

$1423.855 \mathrm{e}-01$

$1434.241 \mathrm{e}-01$

144 4.665e-01

$145 \quad 5.132 \mathrm{e}-01$

$1465.645 \mathrm{e}-01$

$1476.209 \mathrm{e}-01$

148 6.830e-01

$1497.513 e-01$

$1508.264 \mathrm{e}-01$

$1519.091 \mathrm{e}-01$

$1521.000 \mathrm{e}+00$

$1531.125 \mathrm{e}+00$

$1541.266 \mathrm{e}+00$

$1551.424 \mathrm{e}+00$

$1561.602 \mathrm{e}+00$

$1571.802 \mathrm{e}+00$

$1582.027 \mathrm{e}+00$

$1592.281 \mathrm{e}+00$

$1602.566 \mathrm{e}+00$

$1612.887 \mathrm{e}+00$

$1623.247 \mathrm{e}+00$

$1633.653 e+00$

$1644.110 \mathrm{e}+00$

$1654.624 \mathrm{e}+00$

$1665.202 \mathrm{e}+00$

$1675.852 \mathrm{e}+00$

$1686.583 \mathrm{e}+00$

$1697.406 \mathrm{e}+00$

$1708.332 \mathrm{e}+00$

$1719.373 \mathrm{e}+00$

$1721.055 \mathrm{e}+01$

$1731.186 \mathrm{e}+01$

$1741.335 \mathrm{e}+01$

$1752.000 \mathrm{e}+01$ 


\section{APPENDIX D--TALLY GROUP LIMITS FOR NEUTRONS AND PHOTONS}

TALLY GROUP LIMITS FOR NEUTRONS (DEFAULT SET)

$11.307 e-89$

$28.322 e-08$

$34.234 e-07$

$42.0091 \mathrm{e}-06$

$56.737 e-06$

$61.468 e-\not 5$

$72.277 e-65$

$82.940 \mathrm{e}-\not 15$

$94.048 \mathrm{e}-\not 05$

$1 \varnothing 4.918 \mathrm{e}-\not 55$
$116.099 \mathrm{e}-05$

$127.155 \mathrm{e}-85$

$138.431 e-\varnothing 5$

$14.9 .811 \mathrm{e}-\not 55$

$151.338 \mathrm{e}-84$

$161.739 e-\varnothing 4$

$173.267 e-64$

$186.042 e-\varnothing 4$

$191.058 \mathrm{e}-\not 03$

$202.561 \mathrm{e}-83$
$215.763 e-83$

$222.646 \mathrm{e}-\varnothing 2$

$237.002 e-\varnothing 2$

$242.075 e-01$

$253.777 e-81$

$265.123 e-81$

$277.527 e-\varnothing 1$

$281.025 e+\varnothing \varnothing$

$291.338 e+0 \Omega$

$3 \varnothing 1.694 \mathrm{e}+.00$
$312.091 e+\varnothing \varnothing$

$322.53 \varnothing e+\varnothing \varnothing$

$333.611 \mathrm{e}+800$

$343.533 e+\varnothing 9$

$354.0569 \mathrm{e}+.00$

$364.704 \mathrm{e}+78$

$375.3 \mathrm{~b} 3 \mathrm{e} \div 016$

$386.04 .2 \mathrm{E} \times 0 \%$

$396.737 e \div 86$

$4 \varnothing 7.5 \wedge \Omega e+90$
$418.322 e+\varnothing \varnothing$

$429.177 \epsilon+\varnothing \varnothing$

$431 . \varnothing 12 e+\varnothing 1$

$441.101 \mathrm{e}+01$

$451.199 e+\varnothing 1$

$46 \quad 1.307 e+\varnothing 1$

$471.336 e+\infty 1$

$481.413 \mathrm{e}+\varnothing 1$

$491.441 e+01$

$56^{\circ} 1.519 e+\varnothing 1$

2. . DXDe+Ø1

\section{TALLY GROUP LIMITS FOR PHOTONS (DEFAULT SET)}

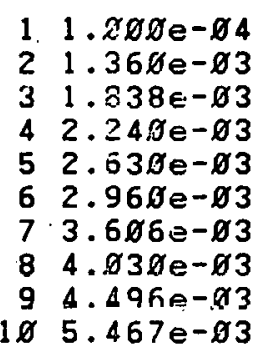
$115.980 \mathrm{e}-\not 3$
12. $6.75 \varnothing e-\varnothing 3$
i3 $7.251 \mathrm{e}-83$
$148.18 \% \mathrm{e}-\varnothing 3$
$158.982 e-83$
$169.560 \mathrm{e}-03$
$171.091 \mathrm{e}-02$
$181.114 \mathrm{e}-02$
$101.393 \mathrm{e} .02$
$201.520 e-\varnothing 2$

\begin{abstract}
$211.7 \varnothing \varnothing e-52$
$221.898 e-82$

$232.095 \mathrm{e}-82$

$242.312 \mathrm{e}-92$

$253.316 e-02$

$26 \quad 4.736 \mathrm{e}-02$

$27.5 .5 \varnothing 9 \mathrm{e}-\varnothing 2$

$28 \cdot 6.746 e-02$

$297.835 \mathrm{e}=252$

$308.795 e-92$
\end{abstract}

$319.6996-92$

$321.997 e-01$

$331.1515 e-91$

$341.351 \mathrm{e}-81$

$351.799 e-91$

$362.394 e-81$

$373.185 e-91$

$38 \quad 4.2 i ! e-91$

उy $5.645 e-91$

$4 \varnothing 7.513 e-81$
$411 . \varnothing \varnothing \varnothing e+\varnothing \varnothing$

$121.124 e+\varnothing 0$

$432.027 e+\varnothing \varnothing$

442.887 e+ 00

$454.110 \mathrm{e}+\varnothing 0$

LE $5.202 e+00$

$476.583 \mathrm{e}+\not \varnothing \varnothing$

$48 \quad 8.332 \mathrm{e}+08$

$491.055 e+\not 11$

$591.335 e+\infty 1$

2. . $00+91$ 
APPENDIX E--LIMITS FOR TALLY TYPES 7, 8, 9, AND 10

COSINES OF ANGULAR DISTRIBUTION LIMITS FOR TALLY TYPES $7,8,9$, AND I

$\begin{array}{llllcll}1 . \varnothing & 1.0 .82 & 9 \varnothing .2 \varnothing & 13-\varnothing .4 \varnothing & 17-\varnothing .9 \varnothing \\ 2 \varnothing .98 & 6 \varnothing .72 & 1 \varnothing \varnothing . \varnothing 5 & 14-\varnothing .6 \varnothing & 18-\varnothing .95 \\ 3 & \varnothing .95 & 7 \varnothing .6 \varnothing & 11-\varnothing . \varnothing 5 & 15-\varnothing .72 & 19-\varnothing .98 \\ 4 \varnothing .9 \varnothing & 8 \varnothing .4 \varnothing & .12-\varnothing .2 \varnothing & 16-\varnothing .82 & & -1 . \varnothing \varnothing\end{array}$

PHOTON ENERGY TALLY GROUP LIMITS FOR TALLY TYPES $7,8,9$, AND 10

$11.00 \theta-\varnothing 4$

$22.62 e-\varnothing 3$

$38.98 e-83$

$41.3 \varnothing e-\varnothing 2$
$52.31 e-62$

$66.75 e-02$

$71.15 e-\varnothing .1$

8. $3.19 e-\varnothing 1$ g $7.51 e-81$

$102 . \varnothing 3 e+\varnothing \varnothing$

$114.11 \mathrm{e}+\varnothing 0$

$128.33 e+\varnothing \varnothing$

NEUTRON ENERGY TALLY GROUP LIMITS FOR TALLY TYPES $7,8,9$, AND $1 \varnothing$

\begin{tabular}{|c|c|c|}
\hline $\begin{array}{ll}1 & 1.31 e-\varnothing 9 \\
2 & 6.71 e-\varnothing 6 \\
3 & 1.34 e-\varnothing 4 \\
4 & 1.06 e-\varnothing 3\end{array}$ & $\begin{array}{ll}5 & 2.07 e-\varnothing 1 \\
6 & 1.02 e 1.00 \\
7 & 3 . \varnothing 1 e+\varnothing \varnothing \\
8 & 5.35 e+\varnothing \varnothing\end{array}$ & $\begin{array}{rr}9 & 7.55 e+\varnothing \varnothing \\
1 \varnothing & 1.01 e+\varnothing 1 \\
11 & 1.2 \varnothing e+\varnothing 1 \\
12 & 1.41 e+\varnothing 1 \\
& 2 . \varnothing \varnothing e+\varnothing 1\end{array}$ \\
\hline
\end{tabular}


The program TALLY resides on the CRAY and was written to list the permanent files, TALLYN or TALLYP, which are created when ITN(G) Tally Options 11,12 , or 16 are chosen in TARTNP.

One input data card is needed with an 11,12 , or 16 punched in Columns (1-2). All data on the file will be listed.

The JCL instructions following the Job and Account Cards will be illustrated. Note that the same ID and PW as used in the TARTNP run must be used.

$A C C E S S, D N=\$ B L D, P D N=T A L L Y, I D=$ GORDO.

ACCESS,DN=FT01, PDN=TALLYN, ID= GORDO, M=XYZ,UQ .

LDR.

$7 / 8 / 9$

data card

$7 / 8 / 9$

If the permanent file is of photon data, use PDN=TALLYP on second card.

Note that DN=FT01 has been accessed in such a way that you can purge it by adding the following instruction after. the LDR card:

UELEIL,UN=rIU1. 
UNL IMITED RELEASE

$$
\text { Do Not film Distr. }
$$

\section{INITIAL DISTRIBUTION}

J. R. Kimlinger, LLNL, L-71 (2)

E. F. Plechaty, LLNL, L-71 (2)

G. H. Rodrigue, LLNL, L-306

K. M. Matzen, 4247

J. E. More 1, 4231

T. P. Wright, 4231

J. H. Renken, 4365

J. S. Philbin, 4452

R. S. Claassen, 8000; Attn:

D. M. 01 son, 8100

A. N. Blackwel 1, 8200

L. Gutierrez, 8400

M. Hall, 8112

D. L. Hartley, 8500

S. G. Peglow, 8112

). M. Stephenson, 8112

G. C. Sluiy, 8112

H. M. Witek, 8112

B. A. Benedetti, 8121

C. S. Hnyle, 8122

B. L. Kistler, 8122

V. D. Revelli, 8122

L. I. Weingarten, 8122

R. J. Gallagher, 8124

J. S. Kraabel, 8124

K. W. Battleson, 8131

D. K. Deàii, 8131

P. G. Heppner, 8131

B. F.. Murphey, 8300; Attn:

D. M. Schuster, 8310

K. L. Kinne, 8320

W. Bauer, 8340

K. W. Dolan, 8322

J. Vitko, 8328

G. W. Anderson, 8330; Attn:

R. J. Kee, 8331

R. Y. Lee, 8334

R. E. Hududleston, 8332

G. J. Miller, 8332 (53)

G. B. Drummond, 8336

J. S. Binkley, 8341

L. G. Haggmark: 8341

W. D. Wilson, 8341

W. B. Gauster, 8347

L. W. Dahlke, 8444 (2)

C. T. 0ien, 8444 (2)

Publications Division, 8265 , for TIC (2)

Publications Division, 8265/Technical Library Processes Division, 3141

Technical Library Processes Division, 3141 (3)

M. A. Pound, 8214, for Central Technical Files (3) 


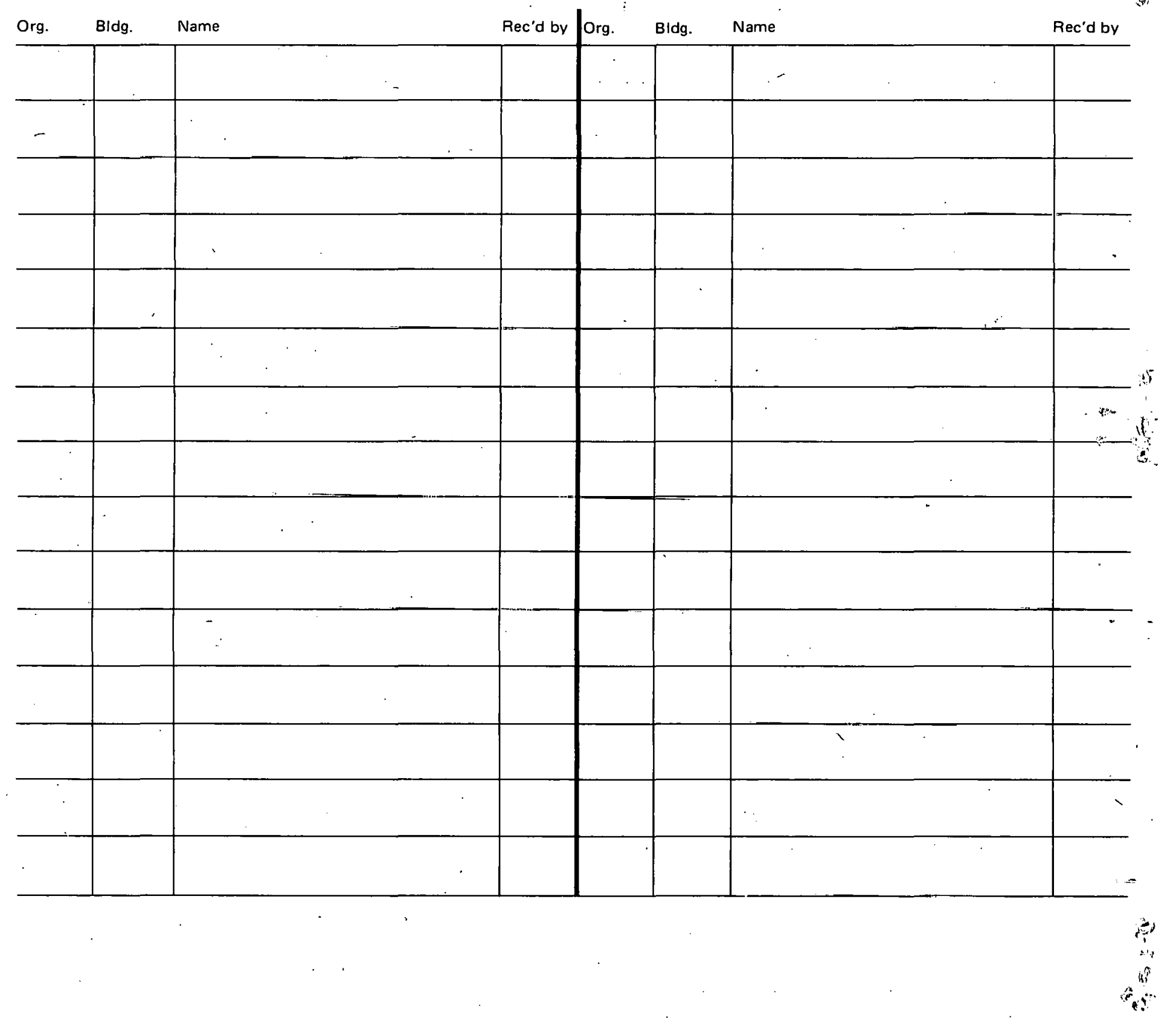

